\title{
Stereoselective Total Synthesis of Macrolide Sch-725674 and C-7-epi-Sch-725674
}

\author{
Karunakar Baikadi \\ Anil Talakokkula \\ A. Venkat Narsaiah* \\ Organic Synthesis Laboratory, Fluoro-Agrochemicals Department, \\ CSIR-Indian Institute of Chemical Technology, Hyderabad, 500007, \\ Telangana, India \\ vnakkirala2001@yahoo.com \\ vnakkirala@csiriict.in
}

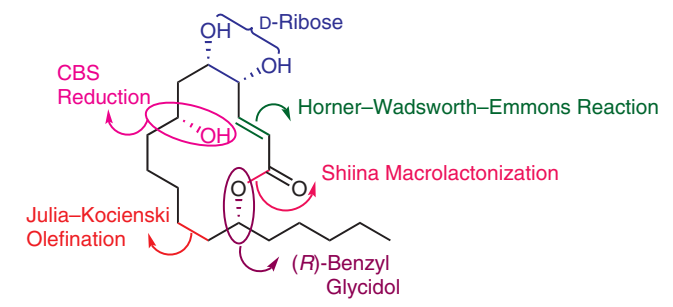

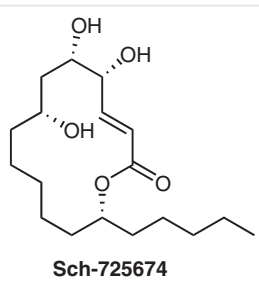

1

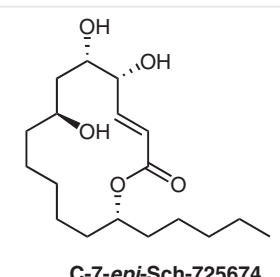

2
Figure 1

As part of our ongoing research program on the synthesis of biologically active natural and synthetic compounds, ${ }^{4}$ we herein report the stereoselective total synthesis of Sch725674 (1) and C-7-epi-Sch-725674 (2) (Figure 1). Our synthetic strategy consisted of Julia-Kocienski olefination, CBS reduction, HWE reaction and Shiina macrolactonization.

As shown in the retrosynthetic analysis (Scheme 1), compound 1, could be obtained from compound 25 via Shiina macrolactonization and global deprotection of both protecting groups. Compound 25 (seco-acid) could be obtained from alkyne 11 and aldehyde $\mathbf{1 5}$ by a nucleophilic addition. The key precursor, alkyne fragment 11, could be obtained from $(R)$-benzyl glycidol and the aldehyde fragment 15 could be obtained from D-ribose.

The synthesis started from commercially available $(R)-$ benzyl glycidol 4, which, on regioselective ring opening with butyl magnesium bromide, ${ }^{5}$ gave the corresponding secondary alcohol 5 in $86 \%$ yield, followed by silylation ${ }^{6}$ with TBSCl and imidazole in $\mathrm{CH}_{2} \mathrm{Cl}_{2}$ to furnish compound $\mathbf{6}$ in excellent yield (Scheme 2). Reductive debenzylation ${ }^{7}$ of compound 6 in the presence of $\mathrm{Pd} / \mathrm{C}(10 \%)$ in EtOAc at room temperature resulted in the formation of primary alcohol 7 
in quantitative yield. The hydroxyl group was oxidized under Swern ${ }^{8}$ conditions to furnish the aldehyde 8, which was directly subjected to Julia-Kocienski olefination ${ }^{9}$ with sulfone $\mathbf{9}$, in the presence of KHMDS, to afford trans olefin $\mathbf{1 0}$ in $87 \%$ yield. The TMS deprotection of compound $\mathbf{1 0}$ was smoothly carried out using $\mathrm{K}_{2} \mathrm{CO}_{3}$ in $\mathrm{MeOH}$ to give compound 11 in $88 \%$ yield, ${ }^{10}$ as shown in the Scheme 2.

Synthesis of the aldehyde fragment started from commercially available D-ribose, which, by the sequential application of reported reactions led to [( $4 R, 5 S)-2,2$-dimethyl-5vinyl-1,3-dioxo lan-4-yl]methanol (12). ${ }^{11}$ The hydroxyl group was silylated ${ }^{12}$ with TBDPSCl / imidazole in $\mathrm{CH}_{2} \mathrm{Cl}_{2}$ to afford 13 in $86 \%$ yield. Hydroboration ${ }^{13}$ of 13 with $\mathrm{BH}_{3} \cdot \mathrm{Me}_{2} \mathrm{~S}$ and subsequent oxidation in the presence of $\mathrm{NaOH} / \mathrm{H}_{2} \mathrm{O}_{2}$ afforded primary alcohol 14 in $89 \%$ yield. This was oxidized under Swern conditions to afford the corresponding aldehyde 15, which was used without purification. At this stage, we coupled the two fragments alkyne $\mathbf{1 1}$ and aldehyde $\mathbf{1 5}$, in the presence of $n$ - $\mathrm{BuLi}^{14}$ at $-78{ }^{\circ} \mathrm{C}$, to achieve the racemic propargylic alcohol 16 and, on subsequent oxidation with

2-iodoxybenzoic acid (IBX) ${ }^{15}$ in DMSO, to the ynone 17 in $81 \%$ yield over two steps.
The asymmetric reduction of ynone 17 was carried out using the CBS reagent ${ }^{16}[(S)-(-)-2-M e-C B S-o x a z a b o r o l i-$ dine] and $\mathrm{BH}_{3} \cdot \mathrm{Me}_{2} \mathrm{~S}$ to give the desired chiral propargylic alcohol 18 in 86\% yield, with excellent stereoselectivity (96:4, $d r$, confirmed by HPLC). The secondary alcohol was converted into its MOM ether 19 by treating with methoxymethyl chloride ${ }^{17}$ and DIPEA in $\mathrm{CH}_{2} \mathrm{Cl}_{2}$. Compound 19 was subjected to hydrogenation ${ }^{18}$ in the presence of $\mathrm{Pd} / \mathrm{C}(10 \%)$ to afford completely saturated compound 20 in $89 \%$ yield; selective desilylation ${ }^{19}$ was then achieved by using $\mathrm{NH}_{4} \mathrm{~F}$ in anhydrous $\mathrm{MeOH}$ at $40{ }^{\circ} \mathrm{C}$ to afford primary alcohol 21 in $84 \%$ yield. The resulting alcohol 21 was oxidized with DessMartin periodinane ${ }^{20}$ in the presence of $\mathrm{NaHCO}_{3}$ in $\mathrm{CH}_{2} \mathrm{Cl}_{2}$ to give the corresponding aldehyde $\mathbf{2 2}$, which was directly subjected to Horner-Wadsworth-Emmons reaction ${ }^{21}$ with triethyl phosphonoacetate and $\mathrm{NaH}$ in THF to give exclusively trans- $(E)-\alpha, \beta$-unsaturated ester 23 in $85 \%$ yield over two steps (Scheme 3).

Compound 23 was desilylated with HF.Py ${ }^{22}$ in THF to afford secondary alcohol $\mathbf{2 4}$ in $90 \%$ yield, followed by baseinduced ester hydrolysis with LiOH to yield seco-acid 25. Seco-acid $\mathbf{2 5}$ cyclized into macrolide $\mathbf{2 6}$ under Shiina macro-

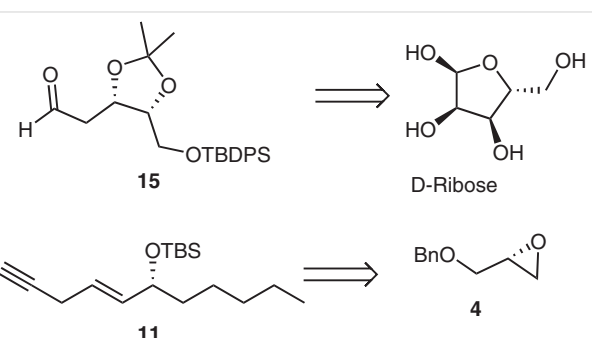

Scheme 1 Retrosynthetic analysis
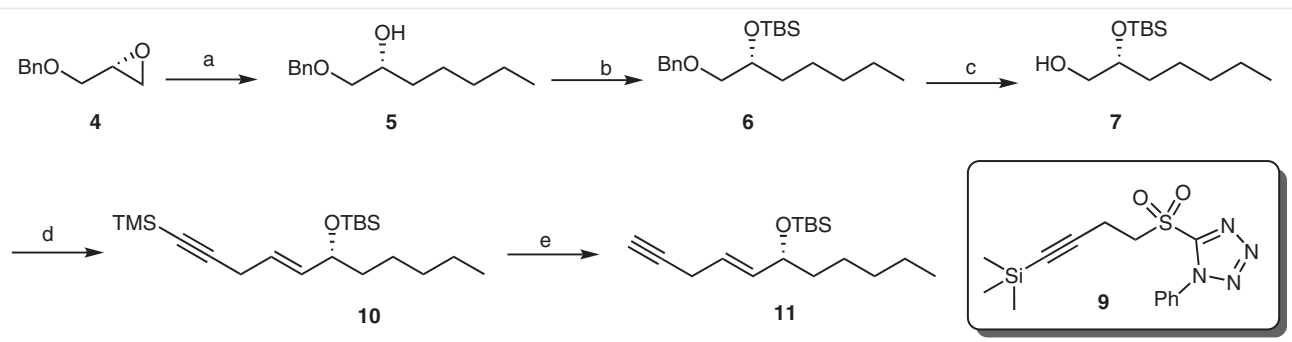

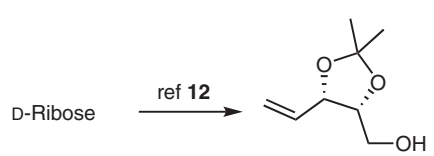

12
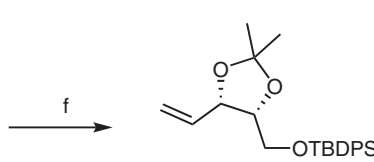

13
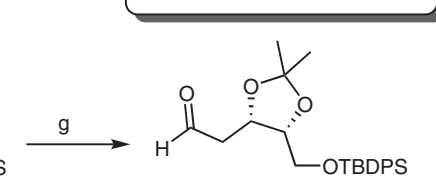

15

Scheme 2 Synthesis of alkyne fragment 11 and aldehyde fragment 15. Reagents and conditions: (a) Butyl magnesium bromide (1.2 equiv), Cul (0.1 equiv), anhydrous THF, $-78{ }^{\circ} \mathrm{C}$ to r.t., $1 \mathrm{~h}, 86 \%$; (b) TBSCl, imidazole, $\mathrm{CH}_{2} \mathrm{Cl}_{2}, 0^{\circ} \mathrm{C}$ to r.t., $1.5 \mathrm{~h}, 88 \%$; (c) $\mathrm{H}_{2}-\mathrm{Pd} / \mathrm{C}$, EtOAc, $8 \mathrm{~h}, 96 \%$; (d) (i) (COCl) $)_{2}$, DMSO, $\mathrm{CH}_{2} \mathrm{C}_{2},-78{ }^{\circ} \mathrm{C}, 2 \mathrm{~h}$; (ii) 9 , $\mathrm{KHMDS}$, anhydrous THF, $-78^{\circ} \mathrm{C}, 1 \mathrm{~h}, 80 \%$ (over two steps); (e) $\mathrm{K}_{2} \mathrm{CO}_{3}$, anhydrous MeOH, r.t., 30 min, $88 \%$; (f) TBDPSCl, imidazole, $\mathrm{CH}_{2} \mathrm{Cl}_{2}, 0{ }^{\circ} \mathrm{C}$ to r.t., $8 \mathrm{~h}, 86 \%$; (g) (i) $\mathrm{BH}_{3} \cdot \mathrm{SMe}_{2}$, THF, $0{ }^{\circ} \mathrm{C}$ to r.t., $1 \mathrm{~h}$; $\mathrm{NaOH}, \mathrm{H}_{2} \mathrm{O}_{2}, 0{ }^{\circ} \mathrm{C}$ to r.t., $2 \mathrm{~h}, 89 \%$ (ii) $(\mathrm{COCl}){ }_{2}, \mathrm{DMSO} \mathrm{CH}_{2} \mathrm{Cl}_{2},-78{ }^{\circ} \mathrm{C}, 2 \mathrm{~h}, 87 \%$. 

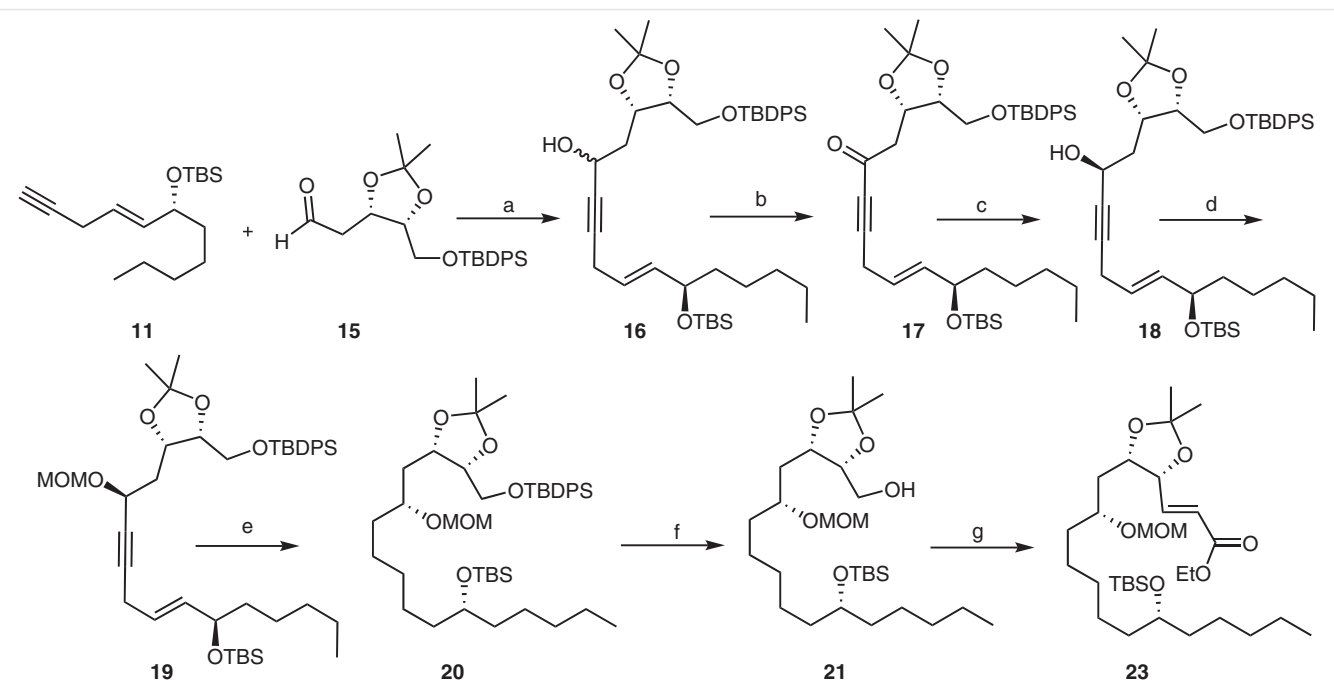

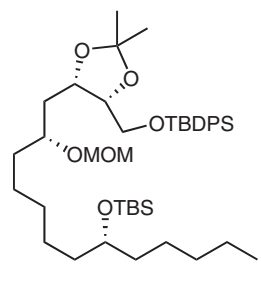

20

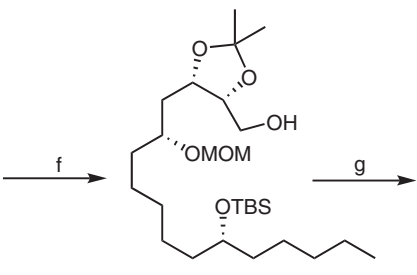

21

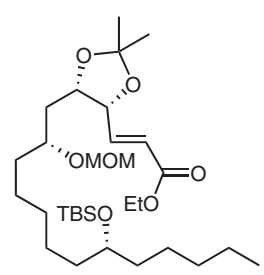

23

Scheme 3 Coupling of alkyne fragment 11 and aldehyde fragment 15. Reagents and conditions: (a) $n$-BuLi, THF, $-78^{\circ} \mathrm{C}, 30 \mathrm{~min}$; (b) IBX, DMSO, THF (1:1), $0{ }^{\circ} \mathrm{C}$ to r.t., $2 \mathrm{~h}, 81 \%$ (over two steps); (c) (S)-(-)-2-Me-CBS-oxazaborolidine (1.0 equiv), $\mathrm{BH}_{3} \cdot \mathrm{Me}_{2} \mathrm{~S}$ ( 1.5 equiv), $\mathrm{THF},-40{ }^{\circ} \mathrm{C}, 1 \mathrm{~h}, 86 \%$; (d) MOM-Cl, DIPEA, $\mathrm{CH}_{2} \mathrm{Cl}_{2}, 0^{\circ} \mathrm{C}$ to r.t., 4 h, $87 \%$; (e) $\mathrm{H}_{2}$, $\mathrm{Pd} / \mathrm{C}$, EtOAc, $1 \mathrm{~h}, 89 \%$; (f) $\mathrm{NH}_{4} \mathrm{~F}, \mathrm{MeOH}, 40{ }^{\circ} \mathrm{C}, 1 \mathrm{~h}, 84 \%$; (g) (i) $\mathrm{DMP}, \mathrm{CH}_{2} \mathrm{Cl}_{2}, \mathrm{NaHCO}_{3}, 0^{\circ} \mathrm{C}$ to r.t., 1 h; (ii) $\mathrm{NaH}$, $(\mathrm{OEt})_{2} \mathrm{P}(\mathrm{O}) \mathrm{CH}_{2} \mathrm{CO}_{2} \mathrm{Et}, \mathrm{THF}, 0{ }^{\circ} \mathrm{C}$ to r.t., $30 \mathrm{~min}, 85 \%$ (over two steps).
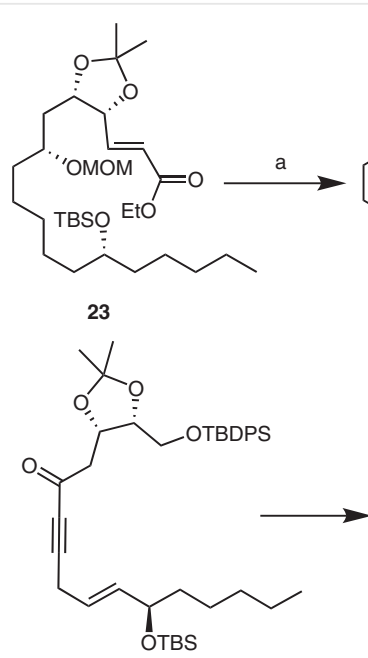

17

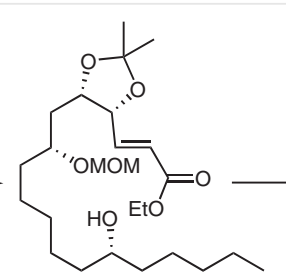

24<smiles>[CH]C(C)(O)O</smiles><smiles>CCCC[C@H](/C=C/C#C[C@@H](O)C[C@H](C)CCO[SbH3])O[SbH3]</smiles>

$18 \mathrm{a}$

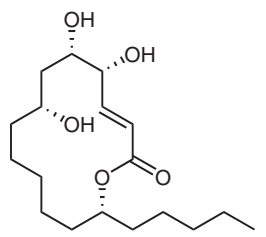

Sch-725674

$\mathrm{OH}$

reaction sequence same as Scheme 3 and Scheme 4
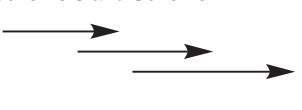

C-7-epi-Sch 725674

Scheme 4 Synthesis of target molecules Sch-725674 and C-7-epi-Sch725674. Reagents and conditions: (a) HF.Py, THF, $0{ }^{\circ} \mathrm{C}$ to r.t., $8 \mathrm{~h}, 90 \%$; (b) (i) LiOH, $\mathrm{THF} / \mathrm{MeOH} / \mathrm{H}_{2} \mathrm{O}(1: 1: 2), 0{ }^{\circ} \mathrm{C}$ to r.t., 3 h; (ii) MNBA, DMAP, toluene, r.t., 8 h, $80 \%$ (over two steps); (c) TFA, THF/MeOH/ $\mathrm{H}_{2} \mathrm{O}(2: 4: 1), 0{ }^{\circ} \mathrm{C}$ to r.t., 2 h, $73 \%$.

lactonization $^{23}$ conditions in $80 \%$ yield over two steps. Removal of both acetonide and MOM ether protecting groups was achieved using trifluoroacetic acid (TFA) ${ }^{24}$ in $\mathrm{THF} / \mathrm{MeOH} / \mathrm{H}_{2} \mathrm{O}(1: 2: 1)$ mixture to afford natural product Sch-725674 (1) in 73\% yield, as shown in Scheme 4.

C-7-Epi-Sch-725674 (2) was achieved by asymmetric reduction of common intermediate ynone 17, using the CBS reagent $[(R)-(+)-2-M e-C B S-o x a z a-b o r o l i d i n e]$ and $\mathrm{BH}_{3} \cdot \mathrm{Me}_{2} \mathrm{~S}$ in THF to give the desired chiral propargyl alcohol 18a in
83\% yield, with excellent stereoselectivity $(98: 2, d r)$, the structure of which was confirmed by ${ }^{1} \mathrm{H}$ NMR analysis. The same reaction sequence was used (Scheme 3 and Scheme 4) for the synthesis of the C-7-epi-Sch-725674. Global removal of the acetonide and MOM ether in macrolides $\mathbf{2 6}$ and 26a was carried out using TFA to afford both target compounds Sch-725674 (1) and C-7-epi-Sch-725674 (2) in good yields. The spectroscopic data and specific rotations of $\mathbf{1}$ and $\mathbf{2}$ are identical with the reported values (Table 1). 
Table 1 NMR Data for Synthetic and Natural 1

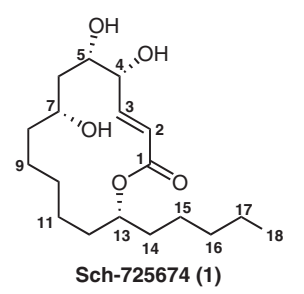

\begin{tabular}{|c|c|c|c|c|}
\hline \multirow[t]{2}{*}{ Position } & \multicolumn{2}{|c|}{$\begin{array}{l}\text { Natural product } \\
{\left[\delta, \mathrm{ppm} \text {,in } \mathrm{CD}_{3} \mathrm{OD}\right]}\end{array}$} & \multicolumn{2}{|c|}{$\begin{array}{l}\text { Synthetic product } \\
{\left[\delta, \mathrm{ppm}, \text { in } \mathrm{CD}_{3} \mathrm{OD}\right]}\end{array}$} \\
\hline & ${ }^{13} \mathrm{C}$ & ${ }^{1} \mathrm{H}(/ \mathrm{Hz})$ & ${ }^{13} \mathrm{C}$ & ${ }^{1} \mathrm{H}(\mathrm{Hz})$ \\
\hline 1 & 168.4 & & 168.4 & \\
\hline 2 & 123.1 & $6.07(\mathrm{dd}, 15.8,1.6)$ & 123.1 & $6.08(\mathrm{dd}, 15.7,1.1)$ \\
\hline 3 & 149.3 & $6.86(\mathrm{dd}, 15.8,6.0)$ & 149.3 & $6.87(\mathrm{dd}, 15.7,5.9)$ \\
\hline 4 & 76.0 & $\begin{array}{l}4.48 \text { (ddd, 6.0, 3.0, } \\
1.6)\end{array}$ & 76.0 & $4.51-4.46(\mathrm{~m})$ \\
\hline 5 & 72.9 & $\begin{array}{l}3.84 \text { (ddd, 6.0, 4.7, } \\
3.0)\end{array}$ & 72.9 & $3.88-3.83(\mathrm{~m})$ \\
\hline 6 & 38.3 & $\begin{array}{l}1.82(\mathrm{ddd}, 14.7,6.5 \\
6.0), 1.65(\mathrm{~m})\end{array}$ & 38.3 & $\begin{array}{l}1.83(\mathrm{dt}, 14.5,5.9) \\
1.66(\mathrm{~m})\end{array}$ \\
\hline 7 & 69.5 & $3.98(q, 6.5)$ & 69.5 & $4.03-3.95(\mathrm{~m})$ \\
\hline 8 & 36.8 & $1.36(\mathrm{~m})$ & 36.8 & $1.36(\mathrm{~m})$ \\
\hline 9 & 25.8 & $1.19(\mathrm{~m}), 1.37(\mathrm{~m})$ & 25.8 & $1.19(\mathrm{~m}), 1.37(\mathrm{~m})$ \\
\hline 10 & 29.5 & $1.15(\mathrm{~m}), 1.40(\mathrm{~m})$ & 29.5 & $1.15(\mathrm{~m}), 1.40(\mathrm{~m})$ \\
\hline 11 & 27.0 & $1.19(\mathrm{~m}), 1.45(\mathrm{~m})$ & 27.0 & $1.19(\mathrm{~m}), 1.45(\mathrm{~m})$ \\
\hline 12 & 34.1 & $1.54(\mathrm{~m}), 1.70(\mathrm{~m})$ & 34.1 & $1.54(\mathrm{~m}), 1.70(\mathrm{~m})$ \\
\hline 13 & 77.6 & $\begin{array}{l}4.94 \text { (dddd, } 9.8,7.5 \text {, } \\
5.0,2.2)\end{array}$ & 77.6 & $4.99-4.91(\mathrm{~m})$ \\
\hline 14 & 36.5 & $1.57(\mathrm{~m}), 1.61(\mathrm{~m})$ & 36.5 & $1.57(\mathrm{~m}), 1.61(\mathrm{~m})$ \\
\hline 15 & 26.4 & $1.32(\mathrm{~m})$ & 26.4 & $1.32(\mathrm{~m})$ \\
\hline 16 & 32.9 & $1.30(\mathrm{~m})$ & 32.9 & $1.30(\mathrm{~m})$ \\
\hline 17 & 23.8 & $1.31(\mathrm{~m})$ & 23.8 & $1.31(\mathrm{~m})$ \\
\hline 18 & 14.5 & $0.89(\mathrm{t}, 6.8)$ & 14.5 & $0.90(\mathrm{t}, 6.6)$ \\
\hline
\end{tabular}

In summary, we have completed the stereoselective total synthesis of Sch-725674 (1) and C-7-epi-Sch-725674 (2) in 14 steps from commercially available D-ribose and $(R)$ benzyl glycidol, with an overall yield of $10.3 \%$. The main features of the synthesis are construction of the alkyne fragment by using Julia Kocienski reaction, generation of a stereogenic center using CBS reduction, and 14-membered lactone formation using Shiina macrolactonization.

All reagents were purchased from commercial sources and were used without further purification. All reactions were performed under an inert atmosphere unless otherwise noted. THF was freshly distilled from $\mathrm{Na}$ /benzophenone ketyl. Petroleum ether refers to the fraction boiling in the $60-80^{\circ} \mathrm{C}$ range. Column chromatography was performed on silica gel (Acme grade 60-120 mesh). All reactions were monitored by TLC to completion (Merck precoated silica gel $60 \mathrm{~F} 254$ plates), visualizing with UV light, in an $\mathrm{I}_{2}$ chamber or with phosphomolybdic acid spray. Melting points were recorded with a Büchi M560 melting point apparatus and are uncorrected. IR spectra were recorded with a Perkin-Elmer FT-IR 240-c spectrometer. ${ }^{1} \mathrm{H}$ NMR spectra were recorded with a Bruker- $400 \mathrm{MHz}$ spectrometer in $\mathrm{CDCl}_{3}$ and $\mathrm{CD}_{3} \mathrm{OD}$ using TMS as internal standard, ${ }^{13} \mathrm{C}$ NMR spectra were recorded on the same instrument operating at $100 \mathrm{MHz}$. Mass spectra were recorded with a Finnigan MAT 1020 mass spectrometer operating at $70 \mathrm{eV}$. Specific rotations were measured with a Rudolph Autopol IV polarimeter at $25^{\circ} \mathrm{C}$.

\section{(R)-1-(Benzyloxy)heptan-2-ol (5)}

To a stirred solution of $\mathrm{CuI}(0.34 \mathrm{~g}, 1.82 \mathrm{mmol})$ in anhydrous THF was added freshly prepared butyl-MgBr solution $(2 \mathrm{M}, 10.9 \mathrm{~mL}, 21.96$ $\mathrm{mmol})$ at $-78{ }^{\circ} \mathrm{C}$. The mixture was stirred for $30 \mathrm{~min},(R)-(-)$-benzyl glycidol ( $3 \mathrm{~g}, 18.3 \mathrm{mmol}$ ) was added and the mixture was stirred for 1 h. On completion, as monitored by TLC, the reaction was quenched with saturated $\mathrm{NH}_{4} \mathrm{Cl}$ solution and the mixture was extracted with EtOAc $(2 \times 25 \mathrm{~mL})$. The combined organic layers were washed with brine $(10 \mathrm{~mL})$, dried over $\mathrm{Na}_{2} \mathrm{SO}_{4}$, filtered and concentrated under reduced pressure. The crude product was purified by column chromatography using silica, eluting with EtOAc-hexane (1:9), to give compound $\mathbf{5}$ as a colorless liquid.

Yield: $3.5 \mathrm{~g}(86 \%) ;[\alpha]_{\mathrm{D}}^{25}-13.5$ (c $1, \mathrm{CHCl}_{3}$ ).

IR (neat): 3396, 2926, 2856, 1454, 1219, 1102, 772, $698 \mathrm{~cm}^{-1}$.

${ }^{1} \mathrm{H}$ NMR $\left(400 \mathrm{MHz}, \mathrm{CDCl}_{3}\right): \delta=7.38-7.26(\mathrm{~m}, 5 \mathrm{H}), 4.55(\mathrm{~s}, 2 \mathrm{H}), 3.85-$ $3.77(\mathrm{~m}, 1 \mathrm{H}), 3.50$ (dd, $J=9.4,3.0 \mathrm{~Hz}, 1 \mathrm{H}), 3.32(\mathrm{dd}, J=9.3,7.7 \mathrm{~Hz}$, $1 \mathrm{H}), 2.48-2.35$ (brs, $1 \mathrm{H}), 1.50-1.23(\mathrm{~m}, 8 \mathrm{H}), 0.88(\mathrm{t}, J=6.8 \mathrm{~Hz}, 3 \mathrm{H})$.

${ }^{13} \mathrm{C}$ NMR $\left(100 \mathrm{MHz}, \mathrm{CDCl}_{3}\right): \delta=137.9,128.3,127.6,74.6,73.2,70.4$, 33.0, 31.8, 25.1, 22.5, 13.9.

HRMS: $m / z[\mathrm{M}+\mathrm{H}]^{+}$calcd for $\mathrm{C}_{14} \mathrm{H}_{23} \mathrm{O}_{2}$ : 223.1693; found: 223.1689 . (R)-\{[1-(Benzyloxy)heptan-2-yl]oxy\}tert-butyldimethylsilane (6)

To a stirred solution of alcohol $5(3.0 \mathrm{~g}, 13.5 \mathrm{mmol})$ in anhydrous $\mathrm{CH}_{2} \mathrm{Cl}_{2}(30 \mathrm{~mL})$ were added imidazole $(1.37 \mathrm{~g}, 20.3 \mathrm{mmol})$ and TBDMS-Cl (2.44 g, $16.2 \mathrm{mmol})$ at $0{ }^{\circ} \mathrm{C}$ and the mixture was stirred at r.t. for $2 \mathrm{~h}$. After completion (monitored by TLC), the mixture was diluted with $\mathrm{CH}_{2} \mathrm{Cl}_{2}(10 \mathrm{~mL})$ and washed with $\mathrm{H}_{2} \mathrm{O}(10 \mathrm{~mL})$, brine $(5$ $\mathrm{mL}$ ), dried over $\mathrm{Na}_{2} \mathrm{SO}_{4}$, filtered and concentrated under reduced pressure. The crude product was purified by column chromatography using silica, eluting with EtOAc-hexane (0.5:9.5), to afford compound 6 as a pale-yellow oil.

Yield: $4.0 \mathrm{~g}(88 \%) ;[\alpha]_{\mathrm{D}}{ }^{25}+10.5$ (c $\left.1.8, \mathrm{CHCl}_{3}\right)$.

IR (neat): 3031, 2954, 2927, 2855, 1463, 1252, 1114, 835, 774, $697 \mathrm{~cm}^{-1}$. ${ }^{1} \mathrm{H}$ NMR $\left(400 \mathrm{MHz}, \mathrm{CDCl}_{3}\right): \delta=7.36-7.31(\mathrm{~m}, 4 \mathrm{H}), 7.30-7.24(\mathrm{~m}, 1 \mathrm{H})$, $4.52(\mathrm{~s}, 2 \mathrm{H}), 3.85-3.77(\mathrm{~m}, 1 \mathrm{H}), 3.42-3.33(\mathrm{~m}, 2 \mathrm{H}), 1.59-1.22(\mathrm{~m}$, $8 \mathrm{H}), 0.88(\mathrm{~s}, 12 \mathrm{H}), 0.05(\mathrm{~s}, 3 \mathrm{H}), 0.04(\mathrm{~s}, 3 \mathrm{H})$.

${ }^{13} \mathrm{C}$ NMR $\left(100 \mathrm{MHz}, \mathrm{CDCl}_{3}\right): \delta=138.5,128.2,127.5,127.4,74.8,73.2$, 71.5, 34.6, 31.9, 25.8, 24.8, 22.6, 18.1, 14.0, -4.3, -4.7.

HRMS: $m / z[\mathrm{M}+\mathrm{H}]^{+}$calcd for $\mathrm{C}_{20} \mathrm{H}_{37} \mathrm{O}_{2} \mathrm{Si}$ : 337.2528; found: 337.2530 .

\section{(R)-2-[(tert-Butyldimethylsilyl)oxy]heptan-1-ol (7)}

To a stirred solution of compound $\mathbf{6}$ (3.78 g, $11.3 \mathrm{mmol}$ ) in EtOAc (30 $\mathrm{mL})$ was added $\mathrm{Pd} / \mathrm{C}(10 \%, 250 \mathrm{mg})$ and the reaction mixture was stirred under hydrogen at r.t. for $12 \mathrm{~h}$. After completion of the reaction (monitored by TLC), the mixture was filtered through Celite ${ }^{\circledR}$, and the pad was washed with EtOAc $(50 \mathrm{~mL})$. The filtrate was evaporated under reduced pressure and the residue was purified by flash column chromatography using silica, eluting with EtOAc-hexane (1:9), to give 7 as a colorless oil.

Yield: $2.65 \mathrm{~g}(96 \%) ;[\alpha]_{\mathrm{D}}^{25}-33.3$ (c 1.2, $\mathrm{CHCl}_{3}$ ). 
IR (neat): 3394, 2954, 2927, 2856, 1464, 1253, 1098, 1046, 834, 774 $\mathrm{cm}^{-1}$.

${ }^{1} \mathrm{H} \mathrm{NMR}\left(400 \mathrm{MHz}, \mathrm{CDCl}_{3}\right): \delta=3.76-3.70(\mathrm{~m}, 1 \mathrm{H}), 3.56(\mathrm{dd}, J=10.9$, $3.5 \mathrm{~Hz}, 1 \mathrm{H}), 3.44$ (dd, $J=10.9,5.4 \mathrm{~Hz}, 1 \mathrm{H}), 1.52-1.45(\mathrm{~m}, 2 \mathrm{H}), 1.35-$ $1.24(\mathrm{~m}, 6 \mathrm{H}), 0.91(\mathrm{~s}, 9 \mathrm{H}), 0.89(\mathrm{t}, J=7.0 \mathrm{~Hz}, 3 \mathrm{H}), 0.09(\mathrm{~s}, 6 \mathrm{H})$.

${ }^{13} \mathrm{C}$ NMR $\left(100 \mathrm{MHz}, \mathrm{CDCl}_{3}\right): \delta=72.9,66.2,33.9,31.9,25.8,24.9,22.5$, $18.0,13.9,-4.4,-4.5$.

HRMS: $m / z[\mathrm{M}+\mathrm{H}]^{+}$calcd for $\mathrm{C}_{13} \mathrm{H}_{31} \mathrm{O}_{2} \mathrm{Si}$ : 247.2089; found: 247.2080. 1-Phenyl-5-\{[4-(trimethylsilyl)but-3-yn-1-yl]sulfonyl\}-1H-tetrazole (9)

To a stirred solution of 4-(trimethylsilyl)-but-3-yn-1-ol (2 g, 14 $\mathrm{mmol})$, in anhydrous THF $(30 \mathrm{~mL})$ were added 5-mercapto-1-phenyl tetrazole (2.5 g, $14 \mathrm{mmol}), \mathrm{PPh}_{3}(3.67 \mathrm{~g}, 14 \mathrm{mmol}$ ) and diisopropylazodicaboxylate $(2.75 \mathrm{~mL}, 14 \mathrm{mmol})$ at $0{ }^{\circ} \mathrm{C}$. The reaction mixture was stirred for $1.5 \mathrm{~h}$ at the same temperature and, after completion of the reaction as monitored by TLC, the reaction was quenched with saturated aq. $\mathrm{NaHCO}_{3}$. The reaction mixture was extracted with EtOAc $(2 \times 20 \mathrm{~mL})$ and the combined organic layers were washed with brine, dried over $\mathrm{Na}_{2} \mathrm{SO}_{4}$, filtered and concentrated under reduced pressure to furnish the crude tetrazole $(3.5 \mathrm{~g})$. To a stirred solution of this tetrazole $(3.5 \mathrm{~g}, 11.57 \mathrm{mmol})$ in $\mathrm{EtOH}(30 \mathrm{~mL})$ were added $\left(\mathrm{NH}_{4}\right)_{6} \mathrm{Mo}_{7} \mathrm{O}_{24} \cdot 4 \mathrm{H}_{2} \mathrm{O}(1.42 \mathrm{~g}, 1.15 \mathrm{mmol})$ and $\mathrm{H}_{2} \mathrm{O}_{2}(13.1 \mathrm{~mL}, 30 \%)$ at $0{ }^{\circ} \mathrm{C}$. The reaction mixture was warmed slowly to r.t. and stirred for a further $1.5 \mathrm{~h}$. After completion of the reaction (monitored by TLC), the solvent was removed under reduced pressure. The reaction was quenched with saturated aq. $\mathrm{NaHCO}_{3}$ and the mixture was extracted with EtOAc $(2 \times 30 \mathrm{~mL})$. The combined organic layers were washed with brine, dried over $\mathrm{Na}_{2} \mathrm{SO}_{4}$, filtered and concentrated under reduced pressure to give the crude product. The crude product was purified by flash column chromatography using silica, eluting with EtOAc-hexane (1:9) mixture, to afford compound $\mathbf{9}$ as a white solid.

Yield: $3.6 \mathrm{~g}$ (78\% over two steps).

IR (neat): 2960, 2180, 1498, 1353, 1147, 842, 769, $690 \mathrm{~cm}^{-1}$.

${ }^{1} \mathrm{H} \mathrm{NMR}\left(400 \mathrm{MHz}, \mathrm{CDCl}_{3}\right): \delta=7.71-7.57(\mathrm{~m}, 5 \mathrm{H}), 3.90(\mathrm{t}, J=7.5 \mathrm{~Hz}$, $2 \mathrm{H}), 2.93$ (t, J = 7.5 Hz, $2 \mathrm{H}), 0.14(\mathrm{~s}, 9 \mathrm{H})$.

${ }^{13} \mathrm{C}$ NMR $\left(100 \mathrm{MHz}, \mathrm{CDCl}_{3}\right): \delta=153.0,132.8,131.5,129.6,125.1,99.7$, 88.4, 54.6, 14.5, -0.2 .

HRMS: $m / z[\mathrm{M}+\mathrm{H}]^{+}$calcd for $\mathrm{C}_{14} \mathrm{H}_{19} \mathrm{~N}_{4} \mathrm{O}_{2} \mathrm{SSi}$ : 335.09926; found: 335.09925.

\section{$(R, E)$-tert-Butyldimethyl-\{[1-(trimethylsilyl)undec-4-en-1-yn-6- yl]oxy\}silane (10)}

To a stirred solution of oxalyl chloride $(1.35 \mathrm{~mL}, 15.8 \mathrm{mmol})$ in anhydrous $\mathrm{CH}_{2} \mathrm{Cl}_{2}(5 \mathrm{~mL})$ was added DMSO ( $\left.2.41 \mathrm{~mL}, 33.8 \mathrm{mmol}\right)$ slowly at $-78{ }^{\circ} \mathrm{C}$ and the mixture was stirred for $30 \mathrm{~min}$. Then a solution of alcohol 6 (2.6 g, $10.6 \mathrm{mmol}$ ) in anhydrous $\mathrm{CH}_{2} \mathrm{Cl}_{2}(10 \mathrm{~mL})$ was added at $-78{ }^{\circ} \mathrm{C}$ and the mixture was stirred for another $3 \mathrm{~h}$ at the same temperature. $\mathrm{Et}_{3} \mathrm{~N}(5.8 \mathrm{~mL}, 42.2 \mathrm{mmol})$ was added at $0{ }^{\circ} \mathrm{C}$, the mixture was stirred for a further 45 minutes, the reaction was quenched with water $(20 \mathrm{~mL})$ and the mixture was extracted with $\mathrm{CH}_{2} \mathrm{Cl}_{2}(2 \times 20 \mathrm{~mL})$. The combined organic layers were washed with brine, dried over $\mathrm{Na}_{2} \mathrm{SO}_{4}$, filtered and concentrated to give crude aldehyde $\mathbf{8}$ as a paleyellow syrup ( $2.2 \mathrm{~g}$ ). To a stirred solution of sulfone $\mathbf{9}$ (3.6 g, 10.8 $\mathrm{mmol})$ in anhydrous THF $(40 \mathrm{~mL})$ under argon was added KHMDS (9.9 $\mathrm{mL} 1 \mathrm{M}, 9.9 \mathrm{mmol}$ ) at $-78{ }^{\circ} \mathrm{C}$ and the mixture was stirred for $10 \mathrm{~min}$ utes. Then aldehyde $\mathbf{8}(2.2 \mathrm{~g}, 9.0 \mathrm{mmol})$ dissolved in anhydrous THF $(10 \mathrm{~mL})$ was added and the mixture was stirred for $30 \mathrm{~min}$ at the same temperature. The reaction mixture was warmed slowly to r.t. and stirring was continued for $1 \mathrm{~h}$. The reaction was quenched with saturated aq. $\mathrm{NH}_{4} \mathrm{Cl}(10 \mathrm{~mL})$ and the mixture was extracted with EtOAc $(2 \times 30 \mathrm{~mL})$. The combined organic layers were washed with
$\mathrm{H}_{2} \mathrm{O}$, brine, dried over $\mathrm{Na}_{2} \mathrm{SO}_{4}$, filtered and concentrated under reduced pressure. The crude product was purified by flash column chromatography using silica, eluting with EtOAc-hexane (0.3:9.7), to give $\mathbf{1 0}$ as a colorless liquid.

Yield: $2.98 \mathrm{~g}$ (80\% over two steps); $[\alpha]_{\mathrm{D}}^{25}-9.0$ (c 1.0, $\mathrm{CHCl}_{3}$ ). IR (neat): 2956, 2929, 2856, 2177, 1467, 1250, 1076, 836, $772 \mathrm{~cm}^{-1}$. ${ }^{1} \mathrm{H}$ NMR $\left(400 \mathrm{MHz}, \mathrm{CDCl}_{3}\right): \delta=5.68(\mathrm{ddt}, J=15.2,6.3,1.5 \mathrm{~Hz}, 1 \mathrm{H})$, 5.51 (dtd, $J=15.2,5.3,0.9 \mathrm{~Hz}, 1 \mathrm{H}), 4.12-4.04(\mathrm{~m}, 1 \mathrm{H}), 2.99-2.93(\mathrm{~m}$, $2 \mathrm{H}), 1.51-1.23(\mathrm{~m}, 8 \mathrm{H}), 0.89(\mathrm{~s}, 9 \mathrm{H}), 0.88(\mathrm{t}, J=5.0 \mathrm{~Hz}, 3 \mathrm{H}), 0.16(\mathrm{~s}$, $9 \mathrm{H}), 0.05(\mathrm{~s}, 3 \mathrm{H}), 0.03(\mathrm{~s}, 3 \mathrm{H})$.

${ }^{13} \mathrm{C}$ NMR $\left(100 \mathrm{MHz}, \mathrm{CDCl}_{3}\right): \delta=135.5,123.2,104.1,86.4,73.0,38.1$, $31.7,25.9,24.9,22.7,22.6,14.0,0.06,-4.2,-4.7$.

HRMS: $m / z[\mathrm{M}+\mathrm{Na}]^{+}$calcd for $\mathrm{C}_{20} \mathrm{H}_{40} \mathrm{OSi}_{2} \mathrm{Na}$ : 375.2690; found: 375.2694.

\section{(R,E)-tert-Butyldimethyl(undec-4-en-1-yn-6-yloxy)silane (11)}

To a stirred solution of compound $\mathbf{1 0}(2.85 \mathrm{~g}, 8.1 \mathrm{mmol})$ in anhydrous $\mathrm{MeOH}$ was added $\mathrm{K}_{2} \mathrm{CO}_{3}(3.35 \mathrm{~g}, 24.3 \mathrm{mmol})$ at $0{ }^{\circ} \mathrm{C}$ and the mixture allowed to stir at r.t. for $20 \mathrm{~min}$. After completion of the reaction, as monitored by TLC, the reaction was quenched with saturated $\mathrm{NH}_{4} \mathrm{Cl}$ solution and the solvent was evaporated under vacuum. The reaction mixture was extracted with EtOAc $(2 \times 25 \mathrm{~mL})$, the combined organic layers were washed with brine, dried over $\mathrm{Na}_{2} \mathrm{SO}_{4}$, filtered and concentrated under vacuum to furnish the crude product. The crude product was purified by column chromatography using silica, eluting with EtOAc-hexane (0.5:9.5), to afford pure product $\mathbf{1 1}$ as a colorless liquid.

Yield: $2 \mathrm{~g}(88 \%) ;[\alpha]_{\mathrm{D}}^{25}-23.7\left(\mathrm{c} 0.8, \mathrm{CHCl}_{3}\right)$.

IR (neat): 3313, 2955, 2928, 2856, 2178, 1464, 1252, 1075, 968, 833, $773,630 \mathrm{~cm}^{-1}$.

${ }^{1} \mathrm{H}$ NMR $\left(400 \mathrm{MHz}, \mathrm{CDCl}_{3}\right): \delta=5.71(\mathrm{ddt}, J=15.2,6.2,1.6 \mathrm{~Hz}, 1 \mathrm{H})$, $5.53(\mathrm{dtd}, J=15.2,5.4,1.0 \mathrm{~Hz}, 1 \mathrm{H}), 4.11-4.06(\mathrm{~m}, 1 \mathrm{H}), 2.96-2.92(\mathrm{~m}$, $2 \mathrm{H}), 2.09(\mathrm{t}, J=2.7 \mathrm{~Hz}, 1 \mathrm{H}), 1.52-1.40(\mathrm{~m}, 2 \mathrm{H}), 1.34-1.23(\mathrm{~m}, 6 \mathrm{H})$, $0.89(\mathrm{~s}, 9 \mathrm{H}), 0.88(\mathrm{t}, J=5.6 \mathrm{~Hz}, 3 \mathrm{H}), 0.04(\mathrm{~s}, 3 \mathrm{H}), 0.03(\mathrm{~s}, 3 \mathrm{H})$.

${ }^{13} \mathrm{C}$ NMR $\left(100 \mathrm{MHz}, \mathrm{CDCl}_{3}\right): \delta=135.7,122.9,81.5,72.9,70.0,38.2$, 31.7, 25.9, 24.9, 22.6, 21.2, 14.0, -4.2, -4.7.

HRMS: $m / z[\mathrm{M}+\mathrm{H}]^{+}$calcd for $\mathrm{C}_{17} \mathrm{H}_{33} \mathrm{OSi}$ : 281.2959; found: 281.2962 .

tert-Butyl\{[(4R,5S)-2,2-dimethyl-5-vinyl-1,3-dioxolan-4-yl]methoxy\}diphenylsilane (13)

To a stirred solution of alcohol $12(1.2 \mathrm{~g}, 7.6 \mathrm{mmol})$, in anhydrous $\mathrm{CH}_{2} \mathrm{Cl}_{2}(15 \mathrm{~mL})$ were added imidazole $(0.77 \mathrm{~g}, 11.4 \mathrm{mmol})$ and TBDPS$\mathrm{Cl}(2.4 \mathrm{~mL}, 9.1 \mathrm{mmol})$ at $0{ }^{\circ} \mathrm{C}$, followed by a catalytic amount of DMAP and the mixture was stirred at r.t. for $6 \mathrm{~h}$. After completion of the reaction (monitored by TLC), the mixture was diluted with $\mathrm{CH}_{2} \mathrm{Cl}_{2}(10$ $\mathrm{mL})$, washed with $\mathrm{H}_{2} \mathrm{O}(10 \mathrm{~mL})$, brine $(5 \mathrm{~mL})$, dried over $\mathrm{Na}_{2} \mathrm{SO}_{4}$, filtered and concentrated under reduced pressure. The crude product was purified by column chromatography using silica, eluting with EtOAc-hexane (0.5:9.5), to give $\mathbf{1 0}$ as a colorless liquid.

Yield: $2.6 \mathrm{~g}(86 \%) ;[\alpha]_{D}{ }^{25}-3.9\left(c 1.1, \mathrm{CHCl}_{3}\right)$. IR (neat): 3071, 2931, 2858, 1428, 1216, 1109, 1084, 772, $703 \mathrm{~cm}^{-1}$. $\left.{ }^{1} \mathrm{H} \mathrm{NMR} \mathrm{(400} \mathrm{MHz,} \mathrm{CDCl}_{3}\right): \delta=7.69-7.65(\mathrm{~m}, 4 \mathrm{H}), 7.44-7.35(\mathrm{~m}, 6 \mathrm{H})$, 5.97-5.89 (m, $1 \mathrm{H}), 5.36(\mathrm{dt}, J=17.2,1.0 \mathrm{~Hz}, 1 \mathrm{H}), 5.21(\mathrm{dt}, J=10.3$, $0.9 \mathrm{~Hz}, 1 \mathrm{H}), 4.68-4.63(\mathrm{~m}, 1 \mathrm{H}), 4.30-4.26(\mathrm{~m}, 1 \mathrm{H}), 3.72-3.63(\mathrm{~m}$, $2 \mathrm{H}), 1.44(\mathrm{~s}, 3 \mathrm{H}), 1.37$ (s, $3 \mathrm{H}), 1.05(\mathrm{~s}, 9 \mathrm{H})$.

${ }^{13} \mathrm{C}$ NMR $\left(100 \mathrm{MHz}, \mathrm{CDCl}_{3}\right): \delta=135.5,133.6,133.4,133.3,129.6$, 127.6, 117.9, 108.5, 78.7, 78.4, 62.8, 27.7, 26.7, 25.3, 19.1 .

HRMS: $m / z\left[\mathrm{M}+\mathrm{NH}_{4}\right]^{+}$calcd for $\mathrm{C}_{24} \mathrm{H}_{36} \mathrm{O}_{3} \mathrm{SiN}$ : 414.2194; found: 414.2199. 
2-\{(4S,5R)-5-[((tert-Butyldiphenylsilyl)oxy)methyl]-2,2-dimethyl1,3-dioxolan-4-yl\} ethan-1-ol (14)

To a stirred solution of compound $\mathbf{1 3}(2.3 \mathrm{~g}, 5.8 \mathrm{mmol})$ in anhydrous THF $(30 \mathrm{~mL})$ was added $\mathrm{BH}_{3} \cdot \mathrm{SMe}_{2}(5.8 \mathrm{~mL}, 11.6 \mathrm{mmol}, 2 \mathrm{M}$, THF) at $0{ }^{\circ} \mathrm{C}$. The reaction mixture was then allowed to warm r.t. and stirred for $2 \mathrm{~h}$. After consumption of starting material (monitored by TLC), the reaction mixture was cooled to $0{ }^{\circ} \mathrm{C}$, then $3 \mathrm{M}$ aq. $\mathrm{NaOH}(8 \mathrm{~mL})$ was added, followed by hydrogen peroxide $(2.5 \mathrm{~mL}, 33 \% \mathrm{w} / \mathrm{w}$ aq. solution) and the mixture was stirred for $2 \mathrm{~h}$ at r.t. The solvent was removed under vacuum, and the residue was extracted with EtOAc $(3 \times 25 \mathrm{~mL})$. The combined organic layers were washed with brine, dried over $\mathrm{Na}_{2} \mathrm{SO}_{4}$, filtered and concentrated under reduced pressure to obtain the crude product, which was purified by column chromatography using silica gel, eluting with EtOAc-hexane (3:7), to afford alcohol 14, as a colorless liquid.

Yield: $2.15 \mathrm{~g}(89 \%) ;[\alpha]_{D}{ }^{25}-29.9\left(c 0.6, \mathrm{CHCl}_{3}\right)$.

IR (neat): 3394, 2932, 2858, 1427, 1217, 1109, 1081, 822, $703 \mathrm{~cm}^{-1}$.

${ }^{1} \mathrm{H} \mathrm{NMR}\left(400 \mathrm{MHz}, \mathrm{CDCl}_{3}\right): \delta=7.68-7.63(\mathrm{~m}, 4 \mathrm{H}), 7.45-7.36(\mathrm{~m}, 6 \mathrm{H})$, 4.41-4.36 (m, $1 \mathrm{H}), 4.26-4.20(\mathrm{~m}, 1 \mathrm{H}), 3.87-3.78(\mathrm{~m}, 2 \mathrm{H}), 3.76-3.69$ (m, $1 \mathrm{H}), 3.68-3.63(\mathrm{~m}, 1 \mathrm{H}), 2.41-2.36(\mathrm{~m}, 1 \mathrm{H}), 1.94-1.87(\mathrm{~m}, 2 \mathrm{H})$, 1.37 (s, $3 \mathrm{H}), 1.33(\mathrm{~s}, 3 \mathrm{H}), 1.05$ (s, $9 \mathrm{H})$.

${ }^{13} \mathrm{C}$ NMR $\left(100 \mathrm{MHz}, \mathrm{CDCl}_{3}\right): \delta=133.5,133.0,132.9,129.7,127.7$, 108.1, 77.6, 77.2, 62.4, 61.4, 31.4, 28.0, 26.7, 25.4, 19.1 .

HRMS: $m / z[\mathrm{M}+\mathrm{H}]^{+}$calcd for $\mathrm{C}_{24} \mathrm{H}_{35} \mathrm{O}_{4} \mathrm{Si}$ : 415.2290; found: 415.2294 .

(R,E)-8-[(tert-Butyldimethylsilyl)oxy]-1-\{(4S,5R)-5-[((tert-butyldiphenylsilyl)oxy)methyl]-2,2-dimethyl-1,3-dioxolan-4-yl\}dodec-6en-3-yn-2-one (17)

To a stirred solution of oxalyl chloride $(0.46 \mathrm{~mL}, 5.43 \mathrm{mmol})$ in anhydrous $\mathrm{CH}_{2} \mathrm{Cl}_{2}(5 \mathrm{~mL})$ was added DMSO $(0.83 \mathrm{~mL}, 11.6 \mathrm{mmol})$ slowly at $-78{ }^{\circ} \mathrm{C}$ and the mixture was stirred for $30 \mathrm{~min}$. Then a solution of alcohol $14(1.5 \mathrm{~g}, 3.62 \mathrm{mmol})$ in anhydrous $\mathrm{CH}_{2} \mathrm{Cl}_{2}(10 \mathrm{~mL})$ was added and the mixture was stirred for another $3 \mathrm{~h}$ at the same temperature. Then, $\mathrm{Et}_{3} \mathrm{~N}(2.5 \mathrm{~mL}, 18.1 \mathrm{mmol})$ was added at $0{ }^{\circ} \mathrm{C}$ and the mixture was stirred for a further 45 minutes. The reaction mixture was diluted with water $(15 \mathrm{~mL})$, extracted with $\mathrm{CH}_{2} \mathrm{Cl}_{2}(2 \times 20 \mathrm{~mL})$, the combined organic layers were washed with brine, dried over $\mathrm{Na}_{2} \mathrm{SO}_{4}$, filtered and concentrated to give crude aldehyde compound $\mathbf{1 5}$ as a pale-yellow syrup ( $1.3 \mathrm{~g}$ ). To a stirred solution of alkyne $\mathbf{1 1}$ ( $1.5 \mathrm{~g}, 5.35$ $\mathrm{mmol})$ in anhydrous THF $(15 \mathrm{~mL})$ was added $n$-BuLi $(3.3 \mathrm{~mL}, 5.3$ mmol, $1.6 \mathrm{M}$, hexane) at $-78{ }^{\circ} \mathrm{C}$ and the mixture was stirred for 20 min. Aldehyde $15(1.3 \mathrm{~g}, 3.15 \mathrm{mmol})$ in anhydrous THF $(10 \mathrm{~mL})$ was added and the reaction mixture was stirred at the same temperature for a further $1 \mathrm{~h}$. The reaction was quenched with saturated aq. $\mathrm{NH}_{4} \mathrm{Cl}$ and the mixture was extracted with EtOAc $(2 \times 20 \mathrm{~mL})$. The combined organic layers were washed with brine, dried over $\mathrm{Na}_{2} \mathrm{SO}_{4}$, filtered and concentrated under reduced pressure. The crude product was purified by column chromatography using silica, eluting with EtOAchexane (1:9), to afford $\mathbf{1 6}$ as an inseparable mixture of diastereoisomers as a yellow oil (yield: $1.98 \mathrm{~g}, 91 \%$ ).

To a stirred solution of IBX $(1.21 \mathrm{~g}, 4.32 \mathrm{mmol})$ in DMSO $(10 \mathrm{~mL})$ was added alcohol $16(1.5 \mathrm{~g}, 2.16 \mathrm{mmol})$ in THF $(10 \mathrm{~mL})$ at $0{ }^{\circ} \mathrm{C}$ and the reaction mixture was then stirred at r.t. for $1 \mathrm{~h}$. After completion of reaction (monitored by TLC), the reaction was quenched with saturated aq. $\mathrm{Na}_{2} \mathrm{~S}_{2} \mathrm{O}_{3}(6 \mathrm{~mL})$ and the mixture was extracted with EtOAc $(2 \times 25 \mathrm{~mL})$. The combined organic layers were washed with cold water, brine, dried over $\mathrm{Na}_{2} \mathrm{SO}_{4}$, filtered and concentrated under reduced pressure. The crude product was purified by column chromatography using silica gel, eluting EtOAc-hexane (0.5:9.5), to afford $\mathbf{1 7}$ as a yellow oil.

Yield: $1.35 \mathrm{~g}$ (81\% for two steps); $[\alpha]_{\mathrm{D}}^{25}-15.6$ ( $\left(\mathrm{c} 1.0, \mathrm{CHCl}_{3}\right)$.
IR (neat): 2924, 2854, 2217, 1679, 1465, 1219, 1075, $772 \mathrm{~cm}^{-1}$. ${ }^{1} \mathrm{H} \mathrm{NMR}\left(400 \mathrm{MHz}, \mathrm{CDCl}_{3}\right): \delta=7.68-7.63(\mathrm{~m}, 4 \mathrm{H}), 7.45-7.36(\mathrm{~m}, 6 \mathrm{H})$, 5.70 (ddt, $J=15.2,5.8,1.4 \mathrm{~Hz}, 1 \mathrm{H}), 5.51$ (dtd, $J=15.4,5.6,1.1 \mathrm{~Hz}, 1 \mathrm{H}$ ), 4.82-4.76 (m, $1 \mathrm{H}), 4.28-4.22(\mathrm{~m}, 1 \mathrm{H}), 4.11-4.06(\mathrm{~m}, 1 \mathrm{H}), 3.68-3.63$ $(\mathrm{m}, 2 \mathrm{H}), 3.13-3.09(\mathrm{~m}, 2 \mathrm{H}), 3.07-3.01(\mathrm{~m}, 1 \mathrm{H}), 2.97-2.89(\mathrm{~m}, 1 \mathrm{H})$, $1.48-1.23(\mathrm{~m}, 14 \mathrm{H}), 1.05(\mathrm{~s}, 9 \mathrm{H}), 0.89(\mathrm{~s}, 9 \mathrm{H}), 0.88(\mathrm{t}, J=6.9 \mathrm{~Hz}, 3 \mathrm{H})$, 0.04 (s, $3 \mathrm{H}), 0.02$ (s, $3 \mathrm{H})$.

${ }^{13} \mathrm{C}$ NMR $\left(100 \mathrm{MHz}, \mathrm{CDCl}_{3}\right): \delta=184.8,137.0,135.5,133.0,132.9$, 129.8, 127.7, 120.7, 108.3, 91.7, 82.0, 77.1, 76.8, 72.8, 62.3, 45.7, 38.0, 31.7, 27.8, 26.8, 25.8, 25.3, 24.8, 22.5, 21.8, 14.0, -4.2, -4.7.

HRMS: $m / z[\mathrm{M}+\mathrm{H}]^{+}$calcd for $\mathrm{C}_{41} \mathrm{H}_{63} \mathrm{O}_{5} \mathrm{Si}$ : 691.42080; found: 691.42085 .

\section{(2S,8R,E)-8-[(tert-Butyldimethylsilyl)oxy]-1-\{(4S,5R)-5-[((tert- butyldiphenylsilyl)oxy)methyl]-2,2-dimethyl-1,3-dioxolan-4- yl\}dodec-6-en-3-yn-2-ol (18)}

To a stirred solution of (S)-CBS (0.86 mL, $0.86 \mathrm{mmol}, 1 \mathrm{M}$, toluene $)$ in anhydrous THF was added a solution of ynone $17(0.6 \mathrm{~g}, 0.86 \mathrm{mmol})$ in anhydrous THF $(5 \mathrm{~mL})$ at $-40{ }^{\circ} \mathrm{C}$, followed by addition of $\mathrm{BH}_{3} \cdot \mathrm{SMe}_{2}$ (1.29 $\mathrm{mL}, 1.29 \mathrm{mmol}, 1 \mathrm{M}$, THF) dropwise over $5 \mathrm{~min}$, and the mixture was then stirred for $1.5 \mathrm{~h}$ at $-40{ }^{\circ} \mathrm{C}$. After completion of reaction (monitored by TLC), the reaction was quenched with $\mathrm{MeOH}(2 \mathrm{~mL})$, the mixture was stirred for another $10 \mathrm{~min}$ and then concentrated under vacuum. The residue was purified by column chromatography using silica, eluting with EtOAc-hexane (1:9), to give alcohol 18 as a colorless oil.

Yield: $0.52 \mathrm{~g}(86 \%) ;[\alpha]_{\mathrm{D}}{ }^{25}-9.9\left(\mathrm{c} 1, \mathrm{CHCl}_{3}\right)$.

IR (neat): 3395, 2955, 2928, 2856, 2318, 1466, 1219, 1110, 1077, 834, $773,703 \mathrm{~cm}^{-1}$.

${ }^{1} \mathrm{H} \mathrm{NMR}\left(400 \mathrm{MHz}, \mathrm{CDCl}_{3}\right): \delta=7.69-7.64(\mathrm{~m}, 4 \mathrm{H}), 7.45-7.36(\mathrm{~m}, 6 \mathrm{H})$, 5.67 (ddt, $J=15.2,6.2,1.5 \mathrm{~Hz}, 1 \mathrm{H}), 5.52(\mathrm{dtd}, J=15.2,5.3,0.9 \mathrm{~Hz}, 1 \mathrm{H})$, 4.72-4.61 (m, $2 \mathrm{H}), 4.27-4.22(\mathrm{~m}, 1 \mathrm{H}), 4.11-4.04(\mathrm{~m}, 1 \mathrm{H}), 3.73-3.63$ $(\mathrm{m}, 2 \mathrm{H}), 3.11(\mathrm{~d}, J=8.5 \mathrm{~Hz}, 1 \mathrm{H}), 3.01-2.96(\mathrm{~m}, 2 \mathrm{H}), 2.11-1.96(\mathrm{~m}$, $2 \mathrm{H}), 1.50-1.21(\mathrm{~m}, 14 \mathrm{H}), 1.05(\mathrm{~s}, 9 \mathrm{H}), 0.89(\mathrm{~s}, 9 \mathrm{H}), 0.87(\mathrm{t}, J=6.9 \mathrm{~Hz}$, $3 \mathrm{H}), 0.04(\mathrm{~s}, 3 \mathrm{H}), 0.02(\mathrm{~s}, 3 \mathrm{H})$.

${ }^{13} \mathrm{C}$ NMR $\left(100 \mathrm{MHz}, \mathrm{CDCl}_{3}\right): \delta=135.55,133.50,133.0,132.9,129.8$, $127.7,123.4,108.3,82.8,82.3,77.5,74.7,73.0,62.3,60.9,38.2,36.1$, 31.7, 28.0, 26.8, 25.9, 25.5, 24.9, 22.6, 21.6, 14.0, -4.1, -4.7.

HRMS: $m / z[\mathrm{M}+\mathrm{Na}]^{+}$calcd for $\mathrm{C}_{41} \mathrm{H}_{64} \mathrm{O}_{5} \mathrm{Si}_{2} \mathrm{Na}$ : 715.4364; found: 715.4369 .

(5S,11R,E)-11-Butyl-5-\{[(4S,5R)-5-(((tert-butyldiphenylsilyl)oxy)methyl)-2,2-dimethyl-1,3-dioxolan-4-yl]methyl\}-13,13,14,14-tetramethyl-2,4,12-trioxa-13-silapentadec-9-en-6-yne (19)

To a stirred solution of $\mathbf{1 8}(0.4 \mathrm{~g}, 0.6 \mathrm{mmol})$ in anhydrous $\mathrm{CH}_{2} \mathrm{Cl}_{2}(6$ $\mathrm{mL})$ at $0{ }^{\circ} \mathrm{C}$ under nitrogen, was added $\operatorname{iPr}_{2} \mathrm{NEt}(0.4 \mathrm{~mL}, 2.3 \mathrm{mmol})$ dropwise. After $5 \mathrm{~min}$, methoxymethyl chloride $(0.09 \mathrm{~mL}, 1.14 \mathrm{mmol})$ was added dropwise and the mixture was stirred for $8 \mathrm{~h}$ at r.t. After completion (monitored by TLC), the reaction was quenched with saturated aq. $\mathrm{NH}_{4} \mathrm{Cl}$ and the mixture was extracted with $\mathrm{CH}_{2} \mathrm{Cl}_{2}(2 \times 10$ $\mathrm{mL}$ ). The combined organic layers were washed with brine, dried over $\mathrm{Na}_{2} \mathrm{SO}_{4}$, filtered and concentrated under vacuum. The crude residue was purified by flash column chromatography using silica, eluting with EtOAc-hexane (0.5:9.5), to afford $\mathbf{1 9}$ as a colorless oil.

Yield: $0.37 \mathrm{~g}(87 \%) ;[\alpha]_{\mathrm{D}}^{25}-18.8$ (c 0.9, $\mathrm{CHCl}_{3}$ ).

IR (neat): 2955, 2927, 2855, 2312, 1219, 1079, $772 \mathrm{~cm}^{-1}$.

${ }^{1} \mathrm{H} \mathrm{NMR}\left(400 \mathrm{MHz}, \mathrm{CDCl}_{3}\right): \delta=7.70-7.65(\mathrm{~m}, 4 \mathrm{H}), 7.44-7.35(\mathrm{~m}, 6 \mathrm{H})$, 5.65 (ddt, $J=15.2,6.2,1.5 \mathrm{~Hz}, 1 \mathrm{H}), 5.51(\mathrm{dtd}, J=15.2,5.3,0.9 \mathrm{~Hz}, 1 \mathrm{H})$, $4.98(\mathrm{~d}, J=6.6 \mathrm{~Hz}, 1 \mathrm{H}), 4.60(\mathrm{~d}, J=6.6 \mathrm{~Hz}, 1 \mathrm{H}), 4.58-4.55(\mathrm{~m}, 1 \mathrm{H})$, 4.49-4.42 (m, $1 \mathrm{H}), 4.21-4.14$ (m, $1 \mathrm{H}), 4.10-4.03$ (m, $1 \mathrm{H}), 3.74-3.61$ 
(m, $2 \mathrm{H}), 3.38$ (s, $3 \mathrm{H}), 2.99-2.93(\mathrm{~m}, 2 \mathrm{H}), 2.18-2.09$ (m, $1 \mathrm{H}), 2.04-$ $1.95(\mathrm{~m}, 1 \mathrm{H}), 1.48-1.20(\mathrm{~m}, 14 \mathrm{H}), 1.05(\mathrm{~s}, 9 \mathrm{H}), 0.88(\mathrm{~s}, 9 \mathrm{H}), 0.87(\mathrm{t}$, $J=5.8 \mathrm{~Hz}, 3 \mathrm{H}), 0.03(\mathrm{~s}, 3 \mathrm{H}), 0.01(\mathrm{~s}, 3 \mathrm{H})$.

${ }^{13} \mathrm{C}$ NMR $\left(100 \mathrm{MHz}, \mathrm{CDCl}_{3}\right): \delta=135.5,135.4,133.3,133.2,129.6$, 127.6, 123.3, 107.9, 93.8, 82.9, 80.5, 77.5, 72.9, 62.5, 62.4, 55.5, 38.2, $36.4,31.7,28.1,26.8,25.9,25.5,24.9,22.6,21.5,14,-4.2,-4.7$.

HRMS: $m / z[\mathrm{M}+\mathrm{Na}]^{+}$calcd for $\mathrm{C}_{43} \mathrm{H}_{68} \mathrm{O}_{6} \mathrm{Si}_{2} \mathrm{Na}$ : 759.4623; found: 759.4626 .

(5R,10R)-5\{[(4S,5R)-5-(((tert-Butyldiphenylsilyl)oxy)methyl)-2,2dimethyl-1,3-dioxolan-4-yl]methyl\}-12,12,13,13-tetramethyl-10pentyl-2,4,11-trioxa-12-silatetradecane (20)

To a stirred solution of $\mathbf{1 9}(0.3 \mathrm{~g}, 0.4 \mathrm{mmol})$ in EtOAc $(8 \mathrm{~mL})$ was added $\mathrm{Pd} / \mathrm{C}(10 \%, 50 \mathrm{mg})$ and the reaction mixture was stirred under a hydrogen atmosphere at r.t. for $2 \mathrm{~h}$. After completion (monitored by TLC), the mixture was filtered through Celite ${ }^{\circledR}$ and the filter pad was washed with EtOAc $(2 \times 10 \mathrm{~mL})$. The filtrate was evaporated in vacuo, and the residue was purified by flash column chromatography using silica, eluting with EtOAc-hexane (0.5:9.5), to give $\mathbf{2 0}$ as a colorless oil.

Yield: $0.27 \mathrm{~g}(89 \%) ;[\alpha]_{\mathrm{D}}{ }^{25}-6.9\left(\mathrm{c} 0.8, \mathrm{CHCl}_{3}\right)$.

IR (neat): 2928, 2856, 1467, 1429, 1252, 1218, 1108, 1043, 834, 772 $\mathrm{cm}^{-1}$.

${ }^{1} \mathrm{H}$ NMR $\left(400 \mathrm{MHz}, \mathrm{CDCl}_{3}\right): \delta=7.69-7.63(\mathrm{~m}, 4 \mathrm{H}), 7.45-7.34(\mathrm{~m}, 6 \mathrm{H})$, $4.69(\mathrm{q}, J=8.8,6.7 \mathrm{~Hz}, 2 \mathrm{H}), 4.45-4.39(\mathrm{~m}, 1 \mathrm{H}), 4.18-4.12(\mathrm{~m}, 1 \mathrm{H})$, 3.83-3.74 (m, $1 \mathrm{H}), 3.70$ (dd, $J=10.5,7.5 \mathrm{~Hz}, 1 \mathrm{H}), 3.65-3.57(\mathrm{~m}, 2 \mathrm{H})$, $3.39(\mathrm{~s}, 3 \mathrm{H}), 1.88-1.79(\mathrm{~m}, 1 \mathrm{H}), 1.77-1.68(\mathrm{~m}, 1 \mathrm{H}), 1.59-1.50(\mathrm{~m}$, $2 \mathrm{H}), 1.44-1.23(\mathrm{~m}, 20 \mathrm{H}), 1.05(\mathrm{~s}, 9 \mathrm{H}), 0.88(\mathrm{~s}, 12 \mathrm{H}), 0.03(\mathrm{~s}, 3 \mathrm{H})$, $0.03(\mathrm{~s}, 3 \mathrm{H})$.

${ }^{13} \mathrm{C}$ NMR $\left(100 \mathrm{MHz}, \mathrm{CDCl}_{3}\right): \delta=135.5,133.3,133.2,129.6,127.6$, 107.7, 95.9, 77.7, 75.0, 73.8, 72.3, 62.6, 55.5, 37.1, 35.4, 34.5, 32.0, $30.2,28.1,26.8,25.9,25.5,25.4,24.99,24.90,22.6,19.1,14.0,-4.3$, 4.4 .

HRMS: $m / z[\mathrm{M}+\mathrm{H}]^{+}$calcd for $\mathrm{C}_{42} \mathrm{H}_{73} \mathrm{O}_{6} \mathrm{Si}_{2}$ : 743.5110; found: 743.5113 .

$\{(4 R, 5 S)-5-[(2 R, 8 R)-8-(($ tert-Butyldimethylsilyl)oxy)-2-(methoxymethoxy)tridecyl]-2,2-dimethyl-1,3-dioxolan-4-yl\}methanol (21)

To a stirred solution of $\mathbf{2 0}$ ( $0.21 \mathrm{~g}, 0.28 \mathrm{mmol})$ in anhydrous $\mathrm{MeOH}$ ( 5 $\mathrm{mL}$ ) was added ammonium fluoride $(0.2 \mathrm{~g}, 5.6 \mathrm{mmol})$ at r.t. The reaction mixture was warmed to $40{ }^{\circ} \mathrm{C}$ and stirred for $1 \mathrm{~h}$. After completion (monitored by TLC), the reaction was quenched with saturated $\mathrm{NH}_{4} \mathrm{Cl}(5 \mathrm{~mL})$, solvent was removed under vacuum and the reaction mixture was extracted with EtOAc $(3 \times 10 \mathrm{~mL})$. The combined organic layers were washed with brine, dried over $\mathrm{Na}_{2} \mathrm{SO}_{4}$ filtered and concentrated under vacuum. The crude product was purified by flash column chromatography using silica, eluting with EtOAc-hexane (4:6), to obtain pure $\mathbf{2 1}$ as a yellow oil.

Yield: $120 \mathrm{mg}(84 \%) ;[\alpha]_{\mathrm{D}}{ }^{25}-51.1\left(\mathrm{c} 0.8, \mathrm{CHCl}_{3}\right)$.

IR (neat): 3395, 2925, 2854, 1463, 1375, 1218, 1038, 834, $772 \mathrm{~cm}^{-1}$.

${ }^{1} \mathrm{H} \mathrm{NMR}\left(400 \mathrm{MHz}, \mathrm{CDCl}_{3}\right): \delta=4.68(\mathrm{q}, J=14.8,6.8 \mathrm{~Hz}, 2 \mathrm{H}), 4.42-4.32$ (m, $1 \mathrm{H}), 4.21-4.12(\mathrm{~m}, 1 \mathrm{H}), 3.83-3.69(\mathrm{~m}, 1 \mathrm{H}), 3.69-3.53(\mathrm{~m}, 3 \mathrm{H})$, $3.39(\mathrm{~s}, 3 \mathrm{H}), 2.22-2.12(\mathrm{~m}, 1 \mathrm{H}), 1.81-1.22(\mathrm{~m}, 25 \mathrm{H}), 0.89(\mathrm{~s}, 12 \mathrm{H})$, $0.03(\mathrm{~s}, 6 \mathrm{H})$.

${ }^{13} \mathrm{C}$ NMR (100 MHz, $\left.\mathrm{CDCl}_{3}\right): \delta=107.7,95.8,77.8,75.2,73.9,72.3,61.7$, 55.7, 37.0, 35.0, 34.1, 32.0, 30.1, 28.1, 25.9, 25.4, 25.2, 24.9, 24.8, 22.6, 14.0, -4.4 .

HRMS: $m / z[M+N a]^{+}$calcd for $\mathrm{C}_{27} \mathrm{H}_{56} \mathrm{O}_{6} \mathrm{SiNa}$ : 527.3919; found: 527.3925 .
Ethyl (E)-3-\{(4R,5S)-5-[(2R,8R)-8-((tert-Butyldimethylsilyl)oxy)(methoxymethoxy)tridecyl]-2,2-dimethyl-1,3-dioxolan-4-yl\}acrylate (23)

To a stirred solution of alcohol 21 (105 $\mathrm{mg}, 0.208 \mathrm{mmol}$ ) in anhydrous $\mathrm{CH}_{2} \mathrm{Cl}_{2}(3 \mathrm{~mL})$ were added Dess-Martin periodinane $(114 \mathrm{mg}, 0.27$ $\mathrm{mmol})$ and $\mathrm{NaHCO}_{3}(34 \mathrm{mg}, 0.42 \mathrm{mmol})$ at $0{ }^{\circ} \mathrm{C}$ and the mixture was stirred at r.t. for $1 \mathrm{~h}$. After completion (monitored by TLC), the reaction was quenched with saturated aq. $\mathrm{Na}_{2} \mathrm{~S}_{2} \mathrm{O}_{3}(10 \mathrm{~mL})$ and saturated aq. $\mathrm{NaHCO}_{3}(10 \mathrm{~mL})$ and the mixture was extracted with $\mathrm{CH}_{2} \mathrm{Cl}_{2}$ $(2 \times 20 \mathrm{~mL})$. The extracts were washed sequentially with water, brine, dried over $\mathrm{Na}_{2} \mathrm{SO}_{4}$, filtered and concentrated under vacuum to give the corresponding aldehyde $\mathbf{2 2}$, which was used in the next step without further purification. Triethyl phosponoacetate $(87 \mathrm{mg}, 0.39$ $\mathrm{mmol}$ ) was added to a stirred suspension of $\mathrm{NaH}(14 \mathrm{mg}, 0.35 \mathrm{mmol})$ in anhydrous $\mathrm{THF}(3 \mathrm{~mL})$ at $0{ }^{\circ} \mathrm{C}$. The resulting solution was stirred for $45 \mathrm{~min}$ at $0{ }^{\circ} \mathrm{C}$, then aldehyde $22(100 \mathrm{mg}, 0.195 \mathrm{mmol})$ in anhydrous THF ( $3 \mathrm{~mL})$ was added and the resulting mixture was stirred at r.t. for $1 \mathrm{~h}$. After completion (monitored by TLC), the reaction was quenched by adding saturated aq. $\mathrm{NH}_{4} \mathrm{Cl}(10 \mathrm{~mL})$, and the mixture was extracted with EtOAc $(2 \times 20 \mathrm{~mL})$. The organic extracts were washed with brine $(10 \mathrm{~mL})$, dried $\left(\mathrm{Na}_{2} \mathrm{SO}_{4}\right)$, filtered and concentrated under reduced pressure. The crude material was purified by column chromatography using silica, eluting with EtOAc-hexane (1:9), to give $\mathbf{2 3}$ as a colorless liquid.

Yield: $101 \mathrm{mg}$ (85\% over two steps); $[\alpha]_{\mathrm{D}}^{25}+63.3\left(\mathrm{c} 0.5, \mathrm{CHCl}_{3}\right)$. IR (neat): 2927, 2854, 1726, 1467, 1375, 1219, 1040, 835, $772 \mathrm{~cm}^{-1}$. ${ }^{1} \mathrm{H} \mathrm{NMR}\left(400 \mathrm{MHz}, \mathrm{CDCl}_{3}\right): \delta=6.84(\mathrm{dd}, J=15.5,5.8 \mathrm{~Hz}, 1 \mathrm{H}), 6.07(\mathrm{dd}$, $J=15.5,1.4 \mathrm{~Hz}, 1 \mathrm{H}), 4.71-4.62(\mathrm{~m}, 2 \mathrm{H}), 4.50-4.43(\mathrm{~m}, 1 \mathrm{H}), 4.21(\mathrm{q}$, $J=14.3,7.2 \mathrm{~Hz}, 2 \mathrm{H}), 3.78-3.69(\mathrm{~m}, 1 \mathrm{H}), 3.65-3.57(\mathrm{~m}, 1 \mathrm{H}), 3.39(\mathrm{~s}$, $3 \mathrm{H}), 1.61-1.20$ (m, $30 \mathrm{H}), 0.88(\mathrm{~s}, 12 \mathrm{H}), 0.03(\mathrm{~s}, 3 \mathrm{H}), 0.03(\mathrm{~s}, 3 \mathrm{H})$.

${ }^{13} \mathrm{C}$ NMR $\left(100 \mathrm{MHz}, \mathrm{CDCl}_{3}\right): \delta=165.9,143.7,123.0,108.7,95.9,77.3$, $74.9,72.3,60.4,55.6,37.0,35.8,35.1,32.0,30.0,29.6,28.0,25.9,25.5$, $25.3,24.99,24.92,22.6,14.2,14.0,-4.4$.

HRMS: $m / z[\mathrm{M}+\mathrm{H}]^{+}$calcd for $\mathrm{C}_{31} \mathrm{H}_{61} \mathrm{O}_{7} \mathrm{Si}$ : 573.4193; found: 573.4187 .

Ethyl (E)-3-\{(4R,5S)-5-[(2R,8R)-8-Hydroxy-2-(methoxymethoxy)tridecyl]-2,2-dimethyl-1,3-dioxolan-4-yl\}acrylate (24)

To a stirred solution of compound $\mathbf{2 3}(95 \mathrm{mg})$ in anhydrous THF was added HF.Py $(0.05 \mathrm{~mL})$ at $0{ }^{\circ} \mathrm{C}$ and the reaction mixture was stirred at r.t. for $8 \mathrm{~h}$. After completion of the reaction (monitored by TLC), the mixture was cooled to $0{ }^{\circ} \mathrm{C}$ and the reaction was quenched with saturated aq. $\mathrm{NaHCO}_{3}(5 \mathrm{~mL})$, followed by $0.05 \mathrm{M} \mathrm{HCl}(5 \mathrm{~mL})$ and the mixture was extracted with EtOAc $(2 \times 10 \mathrm{~mL})$. The combined organic layers were washed with brine, dried over $\mathrm{Na}_{2} \mathrm{SO}_{4}$, filtered and concentrated under reduced pressure. The crude product was purified by flash column chromatography using silica, eluting with EtOAchexane (3:7), to afford pure 22 as a colorless liquid.

Yield: $65 \mathrm{mg}(90 \%) ;[\alpha]_{\mathrm{D}}{ }^{25}+53.3\left(\mathrm{c} 0.2 \mathrm{CHCl}_{3}\right)$.

IR (neat): 3325, 2924, 2854, 1724, 1464, 1373, 1218, 1160, 1035, 772 $\mathrm{cm}^{-1}$.

${ }^{1} \mathrm{H}$ NMR $\left(400 \mathrm{MHz}, \mathrm{CDCl}_{3}\right): \delta=6.84(\mathrm{ddd}, J=15.5,5.9,1.06 \mathrm{~Hz}, 1 \mathrm{H})$, $6.07(\mathrm{dd}, J=15.5,1.2 \mathrm{~Hz}, 1 \mathrm{H}), 4.71-4.64(\mathrm{~m}, 2 \mathrm{H}), 4.51-4.43(\mathrm{~m}, 1 \mathrm{H})$, $4.21(\mathrm{q}, J=14.3,7.1 \mathrm{~Hz}, 2 \mathrm{H}), 3.77-3.70(\mathrm{~m}, 1 \mathrm{H}), 3.63-3.55(\mathrm{~m}, 1 \mathrm{H})$, $3.39(\mathrm{~s}, 3 \mathrm{H}), 1.63-1.25(\mathrm{~m}, 30 \mathrm{H}), 0.89(\mathrm{t}, J=6.2 \mathrm{~Hz}, 3 \mathrm{H})$.

${ }^{13} \mathrm{C}$ NMR $\left(100 \mathrm{MHz}, \mathrm{CDCl}_{3}\right): \delta=166.0,143.8,122.9,108.7,95.9,77.2$, 74.8, 74.8, 71.8, 60.4, 55.6, 37.4, 37.3, 35.8, 35.0, 31.8, 29.7, 28.0, 25.5, 25.4, 25.3, 24.8, 22.6, 14.2, 14.0.

HRMS: $m / z[\mathrm{M}+\mathrm{H}]^{+}$calcd for $\mathrm{C}_{25} \mathrm{H}_{47} \mathrm{O}_{7}: 459.3324$; found: 459.3322 . 
(3aR,8R,14R,15aS,E)-14-(Methoxymethoxy)-2,2-dimethyl-8-pentyl-3a,8,9,10,11,12,13,14,15,15a-decahydro-6H-[1,3]dioxolo[4,5e][1] oxacyclotetradecin-6-one (26)

To a stirred solution of ester $\mathbf{2 4}(45 \mathrm{mg}, 0.098 \mathrm{mmol})$ in a mixture of THF-MeOH- $\mathrm{H}_{2} \mathrm{O}$ (4 mL, 1:1:2) was added LiOH (11 mg, $\left.0.5 \mathrm{mmol}\right)$ at $0^{\circ} \mathrm{C}$ and the mixture was stirred at r.t. for $1.5 \mathrm{~h}$. After completion of the reaction (monitored by TLC), the solvent was removed under vacuum, the residue was extracted with $\mathrm{Et}_{2} \mathrm{O}(5 \mathrm{~mL})$ and the aqueous layer was acidified with $10 \%$ aqueous citric acid solution $(5 \mathrm{~mL})$ at $0{ }^{\circ} \mathrm{C}$ and extracted with EtOAc $(2 \times 10 \mathrm{~mL})$. The combined organic layers were dried over $\mathrm{Na}_{2} \mathrm{SO}_{4}$, filtered and concentrated under reduced pressure to give the crude seco-acid 25 (35 mg). To a stirred solution of 2-methyl-6-nitro benzoic anhydride (MNBA) (33 mg, $0.097 \mathrm{mmol}$ ) in anhydrous toluene $(50 \mathrm{~mL})$ was added DMAP $(59 \mathrm{mg}$, $0.5 \mathrm{mmol}$ ), then seco-acid 25 ( $35 \mathrm{mg}, 0.081 \mathrm{mmol}$ ) in anhydrous toluene $(10 \mathrm{~mL})$ was slowly added by syringe pump at r.t. over $12 \mathrm{~h}$. The reaction mixture was concentrated under vacuum and the residue was purified by column chromatography using silica to afford macrolide $\mathbf{2 6}$ as pale-yellow oil.

Yield: $28 \mathrm{mg}$ (80\% over two steps); $[\alpha]_{\mathrm{D}}^{25}+1.9$ (c $1.1 \mathrm{CHCl}_{3}$ ).

IR (neat): 2922, 2852, 1725, 1465, 1219, 1038, $772 \mathrm{~cm}^{-1}$.

${ }^{1} \mathrm{H} \mathrm{NMR}\left(400 \mathrm{MHz}, \mathrm{CDCl}_{3}\right): \delta=6.77(\mathrm{dd}, J=15.7,8.3 \mathrm{~Hz}, 1 \mathrm{H}), 6.01(\mathrm{dd}$, $J=15.7,0.8 \mathrm{~Hz}, 1 \mathrm{H}), 5.02-4.94(\mathrm{~m}, 1 \mathrm{H}), 4.71-4.65(\mathrm{~m}, 2 \mathrm{H}), 4.64-$ $4.59(\mathrm{~d}, J=6.7 \mathrm{~Hz}, 1 \mathrm{H}), 4.53-4.47(\mathrm{~m}, 1 \mathrm{H}), 3.78-3.70(\mathrm{~m}, 1 \mathrm{H}), 3.37(\mathrm{~s}$, $3 \mathrm{H}), 1.99-1.90$ (m, $1 \mathrm{H}), 1.77-1.69$ (m, $1 \mathrm{H}), 1.69-1.21$ (m, $24 \mathrm{H}), 0.88$ (t, $J=6.8 \mathrm{~Hz}, 3 \mathrm{H})$.

${ }^{13} \mathrm{C}$ NMR $\left(100 \mathrm{MHz}, \mathrm{CDCl}_{3}\right): \delta=165.6,143.6,124.8,108.7,95.1,77.8$, 77.1, 76.0, 75.4, 73.7, 55.6, 35.3, 34.7, 33.7, 31.6, 31.5, 29.6, 29.2, 27.6, 25.0, 25.07, 25.02, 23.9, 22.5, 13.9 .

HRMS: $m / z[\mathrm{M}+\mathrm{Na}]^{+}$calcd for $\mathrm{C}_{23} \mathrm{H}_{40} \mathrm{O}_{6} \mathrm{Na}$ : 435.901; found: 435.2903 . $(5 R, 6 S, 8 R, 14 R, E)-5,6,8$-Trihydroxy-14-pentyloxacyclotetradec-3en-2-one

\section{[Sch-725674 (1)]}

To a stirred solution of compound 24 (20 mg, $0.05 \mathrm{mmol})$ in THF$\mathrm{MeOH}-\mathrm{H}_{2} \mathrm{O}(2 \mathrm{~mL}, 1: 2: 1)$ mixture was added TFA $(0.05 \mathrm{~mL})$ in anhydrous $\mathrm{CH}_{2} \mathrm{Cl}_{2}(1 \mathrm{~mL})$ dropwise at $0{ }^{\circ} \mathrm{C}$. The reaction mixture was slowly warmed to r.t. and stirred for a further $2 \mathrm{~h}$. After completion of the reaction (monitored by TLC), the reaction was quenched with saturated aq. $\mathrm{NaHCO}_{3}(5 \mathrm{~mL})$ and the mixture was extracted with EtOAc $(2 \times 10 \mathrm{~mL})$, the combined organic layers were washed with brine, and dried over $\mathrm{Na}_{2} \mathrm{SO}_{4}$, filtered and concentrated under reduced pressure. The crude product was purified by flash column chromatography using silica, eluting with EtOAc-hexane (3:7), to afford target molecule Sch-725674 (1) as a white solid.

Yield: $11 \mathrm{mg}$ (73\%); $\mathrm{mp} 171-172{ }^{\circ} \mathrm{C} ;[\alpha]_{\mathrm{D}}{ }^{25}+6.2$ (c 1.1, $\left.\mathrm{CHCl}_{3}\right)$ Lit. $^{2}$ +5.15 ( c 0.27, $\mathrm{MeOH})$ \}.

IR (neat): 3395, 2921, 2857, 1704, 1463, 1276, 1219, 1079, $1004 \mathrm{~cm}^{-1}$. ${ }^{1} \mathrm{H}$ NMR (400 MHz, CD $\mathrm{OD}$ ): $\delta=6.87$ (dd, $J=15.7,5.9 \mathrm{~Hz}, 1 \mathrm{H}$ ), 6.08 (dd, $J=15.7,1.1 \mathrm{~Hz}, 1 \mathrm{H}), 4.99-4.91(\mathrm{~m}, 1 \mathrm{H}), 4.51-4.46(\mathrm{~m}, 1 \mathrm{H})$, 4.03-3.95 (m, $1 \mathrm{H}), 3.88-3.83(\mathrm{~m}, 1 \mathrm{H}), 1.83(\mathrm{dt}, J=14.5,5.9 \mathrm{~Hz}, 1 \mathrm{H})$, $1.76-1.49(\mathrm{~m}, 5 \mathrm{H}), 1.45-1.26(\mathrm{~m}, 11 \mathrm{H}), 1.25-1.10(\mathrm{~m}, 3 \mathrm{H}), 0.90(\mathrm{t}, J=$ $6.6 \mathrm{~Hz}, 3 \mathrm{H})$.

${ }^{13} \mathrm{C}$ NMR (100 MHz, $\left.\mathrm{CD}_{3} \mathrm{OD}\right): \delta=168.4,149.3,123.1,77.6,76.0,72.9$, 69.5, 38.3, 36.8, 36.5, 34.1, 32.9, 29.5, 27.0, 26.4, 25.8, 23.8, 14.5 .

HRMS: $m / z[\mathrm{M}+\mathrm{H}]^{+}$cald for $\mathrm{C}_{18} \mathrm{H}_{33} \mathrm{O}_{5}: 329.2330$; found: 329.2328 .
(2R,8R,E)-8-[(tert-Butyldimethylsilyl)oxy]-1-\{(4S,5R)-5-[((tertbutyldiphenylsilyl)oxy)methyl]-2,2-dimethyl-1,3-dioxolan-4yl\}dodec-6-en-3-yn-2-ol (18a)

This was prepared by following the procedure used for $\mathbf{1 8}(0.3 \mathrm{~g}, 0.44$ mmol).

Yield: $0.25 \mathrm{~g}$ (83\%); $[\alpha]_{\mathrm{D}}{ }^{25}-2.9\left(\mathrm{c} 1, \mathrm{CHCl}_{3}\right)$.

IR (neat): 3395, 2955, 2926, 2855, 1466, 1219, 1110, 1076, $772 \mathrm{~cm}^{-1}$.

${ }^{1} \mathrm{H} \mathrm{NMR}\left(400 \mathrm{MHz}, \mathrm{CDCl}_{3}\right): \delta=7.70-7.64(\mathrm{~m}, 4 \mathrm{H}), 7.46-7.35(\mathrm{~m}, 6 \mathrm{H})$, 5.66 (ddt, $J=15.2,6.2,1.5 \mathrm{~Hz}, 1 \mathrm{H}), 5.52(\mathrm{dtd}, J=15.2,5.3,0.9 \mathrm{~Hz}, 1 \mathrm{H})$, 4.69-4.62 (m, $1 \mathrm{H}), 4.46-4.40(\mathrm{~m}, 1 \mathrm{H}), 4.27-4.21(\mathrm{~m}, 1 \mathrm{H}), 4.10-4.03$ (m, $1 \mathrm{H}), 3.73-3.63(\mathrm{~m}, 2 \mathrm{H}), 3.01-2.96(\mathrm{~m}, 2 \mathrm{H}), 2.82-2.77(\mathrm{~m}, 1 \mathrm{H})$, 2.09-2.02 (m, $2 \mathrm{H}), 1.49-1.22(\mathrm{~m}, 14 \mathrm{H}), 1.06(\mathrm{~s}, 9 \mathrm{H}), 0.88(\mathrm{~s}, 9 \mathrm{H})$, $0.87(\mathrm{t}, J=6.8 \mathrm{~Hz}, 3 \mathrm{H}), 0.04(\mathrm{~s}, 3 \mathrm{H}), 0.02(\mathrm{~s}, 3 \mathrm{H})$.

${ }^{13} \mathrm{C}$ NMR $\left(100 \mathrm{MHz}, \mathrm{CDCl}_{3}\right): \delta=135.54,135.50,133.0,132.9,129.7$, 127.7, 123.3, 108.4, 82.7, 82.1, 77.5, 77.1, 75.8, 73.0, 62.3, 61.7, 38.2, 37.6, 31.7, 28.0, 26.8, 25.9, 25.5, 24.9, 22.6, 21.6, 19.1, 14.0, -4.1, -4.7. HRMS: $m / z[\mathrm{M}+\mathrm{Na}]^{+}$calcd for $\mathrm{C}_{41} \mathrm{H}_{64} \mathrm{O}_{5} \mathrm{Si}_{2} \mathrm{Na}$ : 715.4360; found: 715.4369 .

(5R,11R,E)-11-Butyl-5-\{[(4S,5R)-5-(((tert-butyldiphenylsilyl)oxy)methyl)-2,2-dimethyl-1,3-dioxolan-4-yl]methyl\}-13,13,14,14tetramethyl-2,4,12-trioxa-13-silapentadec-9-en-6-yne (19a)

This was prepared by following the procedure used for $\mathbf{1 9}$ from alcohol 18a $(0.2 \mathrm{~g}, 0.3 \mathrm{mmol})$.

Yield: $0.2 \mathrm{~g}(95 \%) ;[\alpha]_{D}{ }^{25}+5.3\left(c 1.5, \mathrm{CHCl}_{3}\right)$.

IR (neat): 2955, 2928, 2856, 2230, 1466, 1428, 1219, $1109 \mathrm{~cm}^{-1}$.

${ }^{1} \mathrm{H} \mathrm{NMR}\left(400 \mathrm{MHz}, \mathrm{CDCl}_{3}\right): \delta=7.69-7.66(\mathrm{~m}, 4 \mathrm{H}), 7.44-7.35(\mathrm{~m}, 6 \mathrm{H})$, 5.66 (ddt, $J=15.2,6.2,1.5 \mathrm{~Hz}, 1 \mathrm{H}), 5.52(\mathrm{dtd}, J=15.2,5.3,0.9 \mathrm{~Hz}, 1 \mathrm{H})$, $4.94(\mathrm{~d}, J=6.7 \mathrm{~Hz}, 1 \mathrm{H}), 4.62-4.56(\mathrm{~m}, 2 \mathrm{H}), 4.47-4.42(\mathrm{~m}, 1 \mathrm{H}), 4.24-$ $4.19(\mathrm{~m}, 1 \mathrm{H}), 4.09-4.04(\mathrm{~m}, 1 \mathrm{H}), 3.76-3.71(\mathrm{~m}, 1 \mathrm{H}), 3.70-3.65(\mathrm{~m}$, $1 \mathrm{H}), 3.35$ (s, $3 \mathrm{H}), 3.01-2.96$ (m, $2 \mathrm{H}), 2.10-1.99$ (m, $2 \mathrm{H}), 1.49-1.22$ (m, $14 \mathrm{H}), 1.05(\mathrm{~s}, 9 \mathrm{H}), 0.88(\mathrm{~s}, 9 \mathrm{H}), 0.87$ (t, J = 5.9 Hz, $3 \mathrm{H}), 0.04(\mathrm{~s}$, $3 \mathrm{H}), 0.01$ (s, $3 \mathrm{H})$.

${ }^{13} \mathrm{C}$ NMR $\left(100 \mathrm{MHz}, \mathrm{CDCl}_{3}\right): \delta=135.6,135.6,133.3,133.2,129.6$, 127.6, 123.3, 108.1, 93.9, 84.1, 79.7, 77.5, 74.3, 73.0, 64.4, 62.5, 55.5, $38.2,35.8,31.7,28.1,26.8,25.9,25.6,24.9,22.6,21.6,19.1,14.0,-4.2$, -4.7 .

HRMS: $m / z[M+N a]^{+}$calcd for $\mathrm{C}_{43} \mathrm{H}_{68} \mathrm{O}_{6} \mathrm{Si}_{2} \mathrm{Na}$ : 759.4620; found: 759.4626 .

(5S,10R)-5-\{[(4S,5R)-5-(((tert-Butyldiphenylsilyl)oxy)methyl)-2,2dimethyl-1,3-dioxolan-4-yl]methyl\}-12,12,13,13-tetramethyl-10pentyl-2,4,11-trioxa-12-silatetradecane (20a)

This was prepared by following the procedure used for $\mathbf{2 0}$ from 19a (192 mg, $0.26 \mathrm{mmol}$ ).

Yield: $183 \mathrm{mg}(95 \%) ;[\alpha]_{\mathrm{D}}^{25}-27.9\left(\mathrm{c} 1, \mathrm{CHCl}_{3}\right)$.

IR (neat): 2929, 2856, 1466, 1377, 1219, 1252, 1109, 1042, 834, 772 $\mathrm{cm}^{-1}$.

${ }^{1} \mathrm{H}$ NMR $\left(400 \mathrm{MHz}, \mathrm{CDCl}_{3}\right): \delta=7.69-7.63(\mathrm{~m}, 4 \mathrm{H}), 7.43-7.34(\mathrm{~m}, 6 \mathrm{H})$, $4.64(\mathrm{q}, J=11.6,6.8 \mathrm{~Hz}, 2 \mathrm{H}), 4.31-4.25(\mathrm{~m}, 1 \mathrm{H}), 4.20-4.14(\mathrm{~m}, 1 \mathrm{H})$, 3.79-3.69 (m, $2 \mathrm{H}), 3.68-3.57(\mathrm{~m}, 2 \mathrm{H}), 3.36(\mathrm{~s}, 3 \mathrm{H}), 1.95-1.80(\mathrm{~m}$, $2 \mathrm{H}), 1.45-1.22(\mathrm{~m}, 22 \mathrm{H}), 1.05$ (s, $9 \mathrm{H}), 0.88$ (s, $12 \mathrm{H}), 0.03(\mathrm{~s}, 3 \mathrm{H})$, $0.03(\mathrm{~s}, 3 \mathrm{H})$.

${ }^{13} \mathrm{C}$ NMR $\left(100 \mathrm{MHz}, \mathrm{CDCl}_{3}\right): \delta=135.56,135.53,133.2,133.1,129.7$, 127.6, 107.9, 95.4, 77.7, 75.4, 74.4, 72.3, 62.6, 55.4, 37.1, 37.0, 34.1, $33.8,32.0,28.1,26.8,25.9,25.6,25.3,25.0,24.9,22.6,19.1,14.0$, $-4.40,-4.41$.

HRMS: $m / z[\mathrm{M}+\mathrm{H}]^{+}$calcd for $\mathrm{C}_{42} \mathrm{H}_{73} \mathrm{O}_{6} \mathrm{Si}_{2}:$ 743.5116; found: 743.5113 . 
$\{(4 R, 5 S)-5-[(2 S, 8 R)-8-(($ tert-Butyldimethylsilyl)oxy)-2-(methoxymethoxy)tridecyl]-2,2-dimethyl-1,3-dioxolan-4-yl\}methanol (21a)

This was prepared by following the procedure used for $\mathbf{2 1}$ from 20a (173 mg, $0.233 \mathrm{mmol}$ ).

Yield: $100 \mathrm{mg}(86 \%) ;[\alpha]_{\mathrm{D}}^{25}+54.0\left(\mathrm{c} 0.5, \mathrm{CHCl}_{3}\right)$.

IR (neat): 3375, 2927, 2855, 1464, 1377, 1219, 1252, 1041, 835, 772 $\mathrm{cm}^{-1}$.

${ }^{1} \mathrm{H} \mathrm{NMR}\left(400 \mathrm{MHz}, \mathrm{CDCl}_{3}\right): \delta=4.73-4.64(\mathrm{~m}, 2 \mathrm{H}), 4.41-4.26(\mathrm{~m}, 1 \mathrm{H})$, 4.20-4.13 (m, $1 \mathrm{H}), 3.79-3.57$ (m, $4 \mathrm{H}), 3.41-3.36$ (m, $2 \mathrm{H}), 1.93-1.83$ (m, $1 \mathrm{H}), 1.79-1.63(\mathrm{~m}, 2 \mathrm{H}), 1.49-1.22(\mathrm{~m}, 24 \mathrm{H}), 0.88(\mathrm{~s}, 12 \mathrm{H}), 0.03$ (s, $3 \mathrm{H}), 0.03$ (s, $3 \mathrm{H})$.

${ }^{13} \mathrm{C} \mathrm{NMR}\left(400 \mathrm{MHz}, \mathrm{CDCl}_{3}\right): \delta=108.0,95.4,77.8,75.2,73.6,72.3,61.6$, 55.5, 37.0, 34.0, 33.4, 32.0, 30.0, 28.2, 25.9, 25.5, 25.2, 25.1, 24.9, 22.6, $14.0,-4.4$.

HRMS: $m / z[\mathrm{M}+\mathrm{Na}]^{+}$calcd for $\mathrm{C}_{27} \mathrm{H}_{56} \mathrm{O}_{6} \mathrm{SiNa}$ : 527.3922; found: 527.3925.

Ethyl (E)-3-\{(4R,5S)-5-[(2S,8R)-8-((tert-Butyldimethylsilyl)oxy)-2(methoxy methoxy)tridecyl]-2,2-dimethyl-1,3-dioxolan-4-yl\}acrylate (23a)

This was prepared by following the procedure used for $\mathbf{2 3}$ from 22a (90 mg, $0.178 \mathrm{mmol}$ ).

Yield: $70 \mathrm{mg}(84 \%) ;[\alpha]_{\mathrm{D}}^{25}-62.4\left(\mathrm{c} 0.5, \mathrm{CHCl}_{3}\right)$.

IR (neat): 2924, 2853, 1724, 1464, 1372, 1218, 1160, 1036, 984, 772 $\mathrm{cm}^{-1}$.

${ }^{1} \mathrm{H} \mathrm{NMR}\left(400 \mathrm{MHz}, \mathrm{CDCl}_{3}\right): \delta=6.83(\mathrm{dd}, J=15.5,6.3 \mathrm{~Hz}, 1 \mathrm{H}), 6.06$ (dd, $J=15.6,1.3 \mathrm{~Hz}, 1 \mathrm{H}$ ), 4.66 (td, $J=6.2,1.3 \mathrm{~Hz}, 1 \mathrm{H}), 4.63$ (s, $2 \mathrm{H}), 4.43-$ $4.33(\mathrm{~m}, 1 \mathrm{H}), 4.20(\mathrm{q}, J=14.3,7.2 \mathrm{~Hz}, 2 \mathrm{H}), 3.70-3.57(\mathrm{~m}, 2 \mathrm{H}), 3.41-$ $3.36(\mathrm{~m}, 3 \mathrm{H}), 1.84-1.72(\mathrm{~m}, 1 \mathrm{H}), 1.63-1.54(\mathrm{~m}, 1 \mathrm{H}), 1.51(\mathrm{~s}, 3 \mathrm{H})$, 1.44-1.22 (m, $24 \mathrm{H}), 0.92-0.85(\mathrm{~m}, 12 \mathrm{H}), 0.03(\mathrm{~s}, 3 \mathrm{H}), 0.03(\mathrm{~s}, 3 \mathrm{H})$.

${ }^{13} \mathrm{C}$ NMR $\left(100 \mathrm{MHz}, \mathrm{CDCl}_{3}\right): \delta=165.8,143.3,123.3,108.9,95.4,77.3$, 75.0, 74.8, 72.3, 60.4, 55.5, 37.0, 34.9, 34.0, 32.0, 30.0, 28.0, 25.9, 25.5, 25.2, 25.1, 24.9, 22.6, 14.2, 14.0, -4.4.

HRMS: $m / z[\mathrm{M}+\mathrm{H}]^{+}$calcd for $\mathrm{C}_{31} \mathrm{H}_{61} \mathrm{O}_{7} \mathrm{Si}$ : 573.4190; found: 573.4187 . Ethyl $(E)-3-\{(4 R, 5 S)-5-[(2 S, 8 R)-8-H y d r o x y-2-(m e t h o x y m e t h o x y) t r i-$ decyl]-2,2-dimethyl-1,3-dioxolan-4-yl\}acrylate (24a)

This was prepared by following the procedure used for $\mathbf{2 4}$ from ester 23a (55 mg, $0.096 \mathrm{mmol}$ ).

Yield: $35 \mathrm{mg}(79 \%) ;[\alpha]_{D}^{25}-33.2\left(c 0.5, \mathrm{CHCl}_{3}\right)$.

IR (neat): 3385, 2923, 2853, 1723, 1463, 1373, 1218, 1034, 882, 772 $\mathrm{cm}^{-1}$.

${ }^{1} \mathrm{H} \mathrm{NMR}\left(400 \mathrm{MHz}, \mathrm{CDCl}_{3}\right): \delta=6.83(\mathrm{dd}, J=15.4,6.3 \mathrm{~Hz}, 1 \mathrm{H}), 6.07(\mathrm{dd}$, $J=15.6,1.3 \mathrm{~Hz}, 1 \mathrm{H}), 4.73-4.59(\mathrm{~m}, 3 \mathrm{H}), 4.47-4.33(\mathrm{~m}, 1 \mathrm{H}), 4.21(\mathrm{q}$, $J=14.3,7.1 \mathrm{~Hz}, 2 \mathrm{H}), 3.73-3.51(\mathrm{~m}, 2 \mathrm{H}), 3.44-32(\mathrm{~m}, 3 \mathrm{H}), 1.86-1.69$ (m, $1 \mathrm{H}), 1.63-1.49(\mathrm{~m}, 4 \mathrm{H}), 1.49-1.22(\mathrm{~m}, 24 \mathrm{H}), 0.89(\mathrm{t}, 3 \mathrm{H}, J=$ $6.6 \mathrm{~Hz})$.

${ }^{13} \mathrm{C}$ NMR $\left(100 \mathrm{MHz}, \mathrm{CDCl}_{3}\right): \delta=165.8,143.4,123.3,108.9,95.4,77.2$, 75.0, 74.8, 71.8, 60.5, 55.6, 37.4, 37.3, 34.9, 34.0, 31.9, 29.6, 28.0, 25.5, 25.3, 25.0, 22.6, 14.2, 14.0.

HRMS: $m / z[\mathrm{M}+\mathrm{H}]^{+}$calcd for $\mathrm{C}_{25} \mathrm{H}_{47} \mathrm{O}_{7}$ : 459.3320; found: 459.3322 .

(3aR,8R,14S,15aS,E)-14-(Methoxymethoxy)-2,2-dimethyl-8-pentyl$3 a, 8,9,10,11,12,13,14,15,15 a-d e c a h y d r o-6 H-[1,3]$ dioxolo[4,5e][1]oxacyclotetradecin-6-one (26a)

This was prepared by following the procedure used for $\mathbf{2 6}$ from secoacid $25 \mathrm{a}(20 \mathrm{mg}, 0.046 \mathrm{mmol})$.

Yield: $16 \mathrm{mg}(84 \%) ;[\alpha]_{\mathrm{D}}^{25}+33\left(\mathrm{c} 1.3, \mathrm{CHCl}_{3}\right)$.
IR (neat): 2923, 2853, 1721, 1460, 1379, 1219, 1041, 989, $772 \mathrm{~cm}^{-1}$. ${ }^{1} \mathrm{H} \mathrm{NMR}\left(400 \mathrm{MHz}, \mathrm{CDCl}_{3}\right): \delta=6.80(\mathrm{dd}, J=15.6,8.9 \mathrm{~Hz}, 1 \mathrm{H}), 6.08(\mathrm{dd}$, $J=15.7,0.7 \mathrm{~Hz}, 1 \mathrm{H}), 5.05-4.97(\mathrm{~m}, 1 \mathrm{H}), 4.68(\mathrm{dd}, J=8.4,6.2 \mathrm{~Hz}, 1 \mathrm{H})$, 4.63-4.58 (m, $1 \mathrm{H}), 4.57-4.46(\mathrm{~m}, 2 \mathrm{H}), 3.41-3.28(\mathrm{~m}, 4 \mathrm{H}), 1.91$ (ddd, $J=14.4,11.4,1.4 \mathrm{~Hz}, 1 \mathrm{H}), 1.77-1.21(\mathrm{~m}, 25 \mathrm{H}), 0.88(\mathrm{t}, J=6.8 \mathrm{~Hz}, 3 \mathrm{H})$. ${ }^{13} \mathrm{C}$ NMR $\left(100 \mathrm{MHz}, \mathrm{CDCl}_{3}\right): \delta=165.1,142.1,125.9,108.7,95.3,76.8$, 75.9, 75.4, 73.5, 55.6, 36.2, 34.9, 34.2, 31.6, 30.4, 28.2, 27.9, 25.28, $25.23,25.20,25.1,22.5,13.9$.

HRMS: $m / z[\mathrm{M}+\mathrm{Na}]^{+}$calcd for $\mathrm{C}_{23} \mathrm{H}_{40} \mathrm{O}_{6} \mathrm{Na}$ : 435.906; found: 435.2903 .

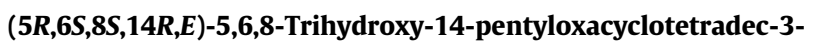
en-2-one [C-7-epi-Sch-725674 (2)]

This was prepared by following the procedure used for natural product Sch-725674 (1) from lactone 26a (14 mg, $0.031 \mathrm{mmol}$ ).

Yield: $8.5 \mathrm{mg}$ (77\%); $[\alpha]_{D}{ }^{25}-39.5$ (c 0.5, $\mathrm{CHCl}_{3}$ ) $\left\{\right.$ Lit. $^{2}-38.6$ (c 0.24, $\mathrm{MeOH})$.

IR (neat): 3395, 2921, 2852, 1714, 1696, 1271, $1219 \mathrm{~cm}^{-1}$.

${ }^{1} \mathrm{H} \mathrm{NMR}\left(400 \mathrm{MHz}, \mathrm{CDCl}_{3}\right): \delta=6.95(\mathrm{dd}, J=15.7,4.2 \mathrm{~Hz}, 1 \mathrm{H}), 6.13$ (dd, $J=15.6,1.8 \mathrm{~Hz}, 1 \mathrm{H}), 4.99-4.89(\mathrm{~m}, 1 \mathrm{H}), 4.57-4.52(\mathrm{~m}, 1 \mathrm{H}), 3.89(\mathrm{dt}$, $J=8.8,2.0 \mathrm{~Hz}, 1 \mathrm{H}), 3.44-3.34(\mathrm{~m}, 1 \mathrm{H}), 2.02(\mathrm{ddd}, J=14.6,8.9,2.4 \mathrm{~Hz}$, $1 \mathrm{H}), 1.70-1.16(\mathrm{~m}, 19 \mathrm{H}), 0.91(\mathrm{t}, J=6.8 \mathrm{~Hz}, 3 \mathrm{H})$.

${ }^{13} \mathrm{C}$ NMR $\left(100 \mathrm{MHz}, \mathrm{CDCl}_{3}\right): \delta=169.0,121.8,75.5,74.9,72.1,68.8$, 40.4, 36.1, 35.9, 33.8, 32.9, 27.2, 26.4, 24.7, 24.5, 23.7, 14.48.

HRMS: $m / z[\mathrm{M}+\mathrm{H}]^{+}$calcd for $\mathrm{C}_{18} \mathrm{H}_{33} \mathrm{O}_{5}$ : 329.2331; found: 329.2328 .

\section{Funding Information}

K.B. and A.T. are grateful to CSIR-New Delhi and UGC-New Delhi, respectively, for providing Fellowships, and the Minister of Science and Technology for providing financial support under DST-SERB-GAP0563.

\section{Acknowledgment}

The authors would like to thank the Director CSIR-IICT for providing facilities. Commun. No: IICT/Pubs./2019/067.

\section{Supporting Information}

Supporting information for this article is available online at https://doi.org/10.1055/s-0037-1611665.

\section{References}

(1) Yang, S. W.; Chan, T. M.; Terracciano, J.; Loebenberg, D.; Patel, M.; Chu, M. J. Antibiot. 2005, 58, 535.

(2) Moretti, J. D.; Wang, X.; Curran, D. P. J. Am. Chem. Soc. 2012, 134, 7963.

(3) (a) Bali, A. K.; Sunnam, S. K.; Prasad, K. R. Org. Lett. 2014, 16, 4001. (b) Sunnam, S. K.; Prasad, K. R. Tetrahedron 2014, 70, 2096. (c) Ramakrishna, K.; Kaliappan, K. P. Org. Biomol. Chem. 2015, 13, 234. (d) Seetharamsingh, B.; Khairnar, P. V.; Reddy, D. S. J. Org. Chem. 2016, 81, 290. (e) Sharma, B. M.; Gontala, A.; Kumar, P. Eur. J. Org. Chem. 2016, 1215. (f) Bodugam, M.; Javed, S.; Ganguly, A.; Torres, J.; Hanson, P. R. Org. Lett. 2016, 18, 516. (g) Reddy, Y.; Sabitha, G. ChemistrySelect 2016, 1, 2156. 
(4) (a) Nagalatha, G.; Narala, S. G.; Narsaiah, A. V. SynOpen 2018, 2, 251. (b) Ghogare, R. S.; Wadavrao, S. B.; Narsaiah, A. V. Helv. Chim. Acta 2016, 99, 247. (c) Wadavrao, S. B.; Ghogare, R. S.; Narsaiah, A. V. Helv. Chim. Acta 2015, 98, 575. (d) Wadavrao, S. B.; Ghogare, R. S.; Narsaiah, A. V. Synthesis 2015, 2129. (e) Narala, S. G.; Nagalatha, G.; Narsaiah, A. V. ARKIVOC 2018, (vii), 495.

(5) (a) Bonini, C.; Chiummiento, L.; Pullez, M.; Solladié, G.; Colobert, F. J. Org. Chem. 2004, 69, 5015. (b) Huang, H.; Mao, C.; Jan, S.-T.; Uckun, F. M. Tetrahedron Lett. 2000, 41, 1699.

(6) (a) Dachavaram, S. S.; Kalyankar, K. B.; Das, S. Tetrahedron Lett. 2014, 55, 5629. (b) Yadav, J. S.; Lakshmi, P. N.; Harshavardhan, S. J.; Reddy, B. V. S. Synlett 2007, 1945. (c) Wadavrao, S. B.; Ghogare, R. S.; Narsaiah, A. V. Tetrahedron Lett. 2012, 53, 3955. (d) Narsaiah, A. V.; Ghogare, R. S. Synthesis 2011, 3271. (e) Wadavrao, S. B.; Ghogare, R. S.; Narsaiah, A. V. Synthesis 2015, 47, 2129.

(7) (a) Evans, D. A.; Dow, R. L.; Shih, T. L.; Takacs, J. M.; Zahler, R. J. Am. Chem. Soc. 1990, 112, 5290. (b) Lowe, J. T.; Wrona, I. E.; Panek, J. S. Org. Lett. 2007, 9, 327.

(8) (a) Clyne, D. S.; Weiler, L. Tetrahedron 1999, 55, 13659. (b) Yadav, J. S.; Thirupathaiah, B.; Singh, V. K.; Ravishashidhar, V. Tetrahedron: Asymmetry 2012, 23, 931. (c) Nakayama, Y.; Maeda, Y.; Hama, N.; Sato, T.; Chida, N. Synthesis 2016, 1647.

(9) Das, S.; Kuilya, T. K.; Goswami, R. K.J. Org. Chem. 2015, 80, 6467.

(10) (a) Yahata, K.; Ye, N.; Iso, K.; Ai, Y.; Lee, J.; Kishi, Y. J. Org. Chem. 2017, 82, 8808. (b) Kesenheimer, C.; Groth, U. Org. Lett. 2006, 8, 2507. (c) Ganganna, B.; Srihari, P.; Yadav, J. S. Tetrahedron Lett. 2017, 58, 2685.
(11) Davies, S. G.; Foster, E. M.; Lee, J. A.; Roberts, P. M.; Thomson, J. E. Tetrahedron: Asymmetry 2014, 25, 534.

(12) (a) Rao, M. V.; Naresh, A.; Saketh, G.; Rao, B. V. Tetrahedron Lett. 2013, 54, 6931. (b) Ghogare, R. S.; Wadavrao, S. B.; Narsaiah, A. V. Tetrahedron Lett. 2013, 54, 5674.

(13) Abe, K.; Kato, K.; Arai, T.; Rahim, M. A.; Sultana, I.; Matsumura, S.; Toshima, K. Tetrahedron Lett. 2004, 45, 8849.

(14) Trost, B. M.; O’Boyle, B. M. J. Am. Chem. Soc. 2008, 130, 16190.

(15) Kirkham, J. E. D.; Courtney, T. D. L.; Lee, V.; Baldwin, J. E. Tetrahedron 2005, 61, 7219.

(16) Hung, D. T.; Nerenberg, J. B.; Schreiber, S. L. J. Am. Chem. Soc. 1996, 118, 11054

(17) (a) Tap, A.; Jouanneau, M.; Galvani, G.; Sorin, G.; Lannou, M.-I.; Férézoub, J.-P.; Ardisson, J. Org. Biomol. Chem. 2012, 10, 8140. (b) Sabitha, G.; Reddy, C. N.; Raju, A.; Yadav, J. S. Tetrahedron: Asymmetry 2011, 22, 493.

(18) Manikanta, G.; Nagaraju, T.; Krishna, P. R. Synthesis 2016, 48, 4213.

(19) Butler, S. C.; Forsyth, C. J. J. Org. Chem. 2013, 78, 3895.

(20) Lebar, M. D.; Baker, B. J. Tetrahedron 2010, 66, 1557.

(21) Si, D.; Sekara, N. M.; Kaliappan, K. P. Org. Biomol. Chem. 2011, 9, 6988.

(22) (a) Njardarson, J. T.; Gaul, C.; Shan, D.; Huang, X.-Y.; Danishefsky, S. J. J. Am. Chem. Soc. 2004, 126, 1038. (b) Reymond, S.; Cossy, J. Tetrahedron 2007, 63, 5918.

(23) (a) Jena, B. K.; Reddy, G. S.; Mohapatra, D. K. Org. Biomol. Chem. 2017, 15, 1863. (b) Kim, H.; Hong, J. Org. Lett. 2010, 12, 2880.

(24) Pandey, S. K.; Kumar, P. Tetrahedron Lett. 2005, 46, 6625. 